\title{
Short Sea Shipping and Innovations for Intermodal Container Logistics in Northeast Asia
}

\author{
Jess Browning* and Seung-Hee Lee**
}

\begin{abstract}
The Incheon Region has numerous assets that fall within a Pentaport model.' These include the Incheon International Airport, the Port of Incheon, a coastal industrial park, free economic zones, a leisure port, and Songdo new town designed to be the future Silicon Valley of Korea. This paper looks at how Northeast Asia trade flows between China and Korea might be enhanced by application of the Pentaport model in making the Incheon region a North East Asian Hub. It looks also at their trade and logistics systems as well as their water borne commerce. It proposes an integrated transportation system for the Yellow Sea Region being beneficial to the economies of the Northeast Asia. It also stresses that innovative technologies for ships, terminals and cargo handling systems should be introduced to develop a competitive short sea shipping system in the region and cooperation among the regional countries will be essential to achieve the final goal. The potential of methods of container shipping is discussed as it might apply to short sea shipping in the Yellow Sea Region that could greatly facilitate Incheon's situation with respect to the broader region in application of the Pentaport model.
\end{abstract}

Keywords : Trade and Logistics, Water Borne Commerce, Short Sea Shipping, Container Shipping, and Innovative Ship, Terminal and Cargo Handling Technologies

- Jess Browning is Director Emeritus, Global Trade, Transportation, and Logistics Studies and Affiliate Professor, Civil \& Environmental Engineering, the University of Washington, Seattle, WA 98195-3550, USA. Email: jessb@u.washington.edu. Ph. D in Economic Geography, University of Washington. Most recent publication is "A Comparative Study of Management Methods (Construction, Control, and Operation) in U.S. and Japan Container Ports", Tokyo: Japan Water Front Journal (Bollard Nippon), March 2000.

" Seung-Hee Lee is Professor of School of Mechanical Engineering and the Research Center for Transportation System of Yellow Sea (CTYS) at Inha University, Incheon, 402-751, Korea. E-mail: shlee@inha.ac.kr Ph. D in Ocean Engineering, Massachusetts Institute of Technology

' Pentaport is a concept announced in the 'Ocean Korea 21' initiative of the Ministry of Maritime Affairs and Fishery, Korea in May 2000. The concept has been refined at Inha University for regional economic development that brings together a cluster of various services in the context of 5 ports - a business port, a techno port, leisure port, airports and sea port (2003). 


\section{BACKGROUND}

Incheon is poised to be the business and logistics hub of Northeast Asia. It is endowed with what is termed invaluable pentaport assets which consists of five ports in one: Incheon International Airport, Incheon seaport, plus a leisure port, a teleport (telecommunications), and a business port. Incheon International Airport has been designed to be the hub airport of Asia; the Port of Incheon, serves as the gate to the Seoul Metropolitan area and central provinces from the Yellow Sea region. As shown in Figure 1, the region is comprised of three free economic zones including a coastal industrial park, a customs free zone locating a logistics park, and the new Songdo town which is destined to be the future business hub of Northeast Asia, namely the Venice in the Orient. ${ }^{2}$ Universities in Incheon provide the academic and educational infrastructure to meet the needs of these geographical and other conditions, thereby make it possible to be a center of higher education in the Northeast Asian Region.

Figure 1. Pentaport Assets of Incheon Metropolitan City

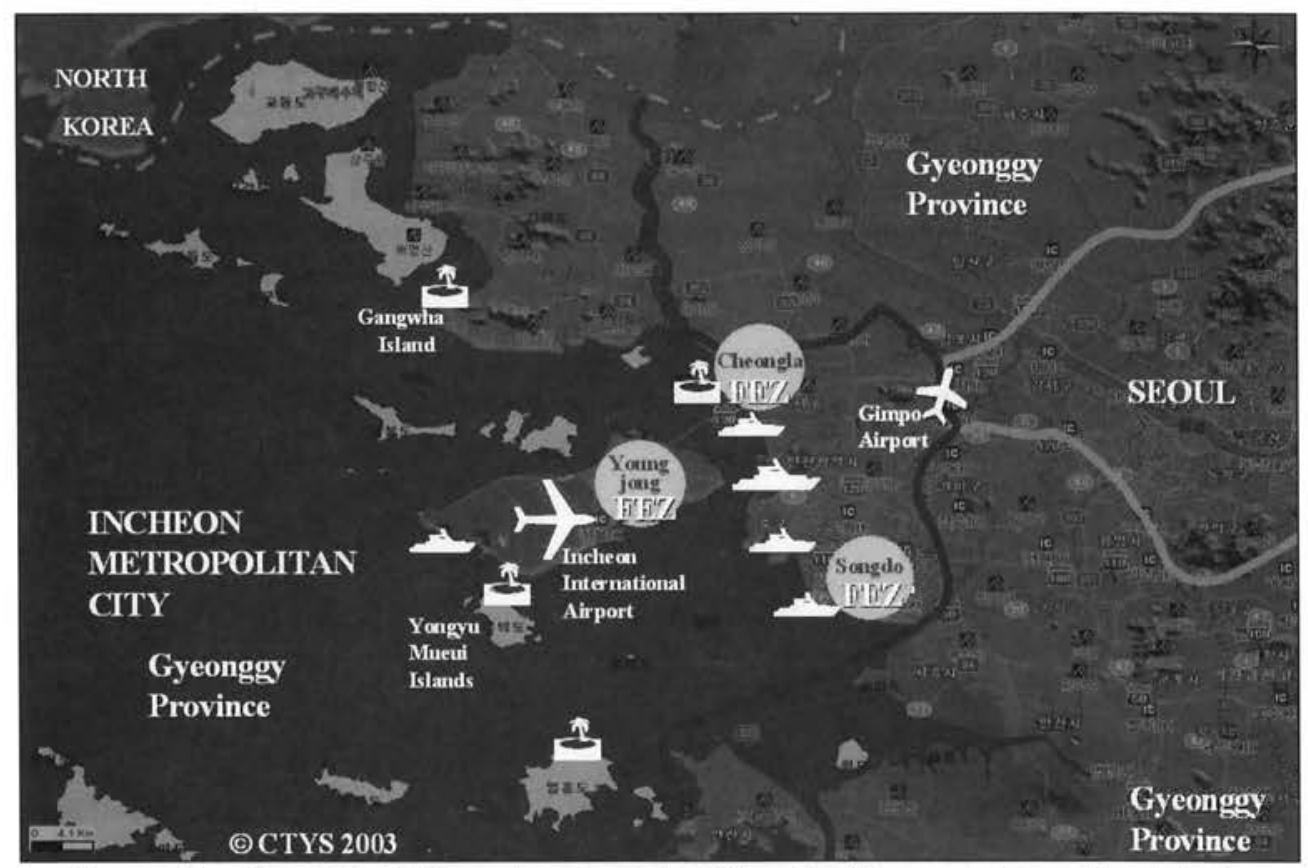

Source : Lee, Seung-Hee,"Future Aspects of the Yellow Sea Transportation and Logistics", Pentaport Seminar to Develop Incheon as Logistics Hub in Northeast Asia, Inha University, October 27 28, 2003.

\footnotetext{
${ }^{2}$ Charm City, Newsweek international, Atlantic Edition, 2004/03/29
} 
The Republic of South Korea and its Incheon area are progressing towards becoming a Northeast Asian economic hub as a result of long range planning by government leaders. This necessitates establishment of an efficient logistics system and includes providing more container berths to handle increased traffic in both containerized cargo and steel between the south coast and Seoul area as well as providing increased capacity to meet the demand for vessels carrying containerized cargo between Korea and other Northeast Asian destinations. Developments around Incheon are also proposed and intended to meet growing Northeast Asian trade and coastal shipping with cargoes destined for the Seoul area and the large Busan container port to the southeast. ${ }^{3}$

The Incheon region will increasingly become a true hub of commerce as developments continue in the creation of logistics, value-added, and distribution facilities along with improved intermodal linkages to enable passengers and freight to move from one mode to another seamlessly, as well as improve its communications and information networks. It requires giving support to foreign companies and foreign investors that want to do business in the region. This is being done in part by designating the free economic zones and by expanding economic cooperation in Northeast Asia, with China and Japan as crucial partners. ${ }^{4}$ The development of better coastal and short sea shipping as well as inland water transport is a critical element in application of the Pentaport model in Incheon area with respect to marine trade and logistics services including education.

This paper looks at how Northeast Asia trade flows between China and Korea might be enhanced by application of the Pentaport model in making the Incheon region a Northeast Asian Hub with respect to development of logistics related services and regional transportation systems. It also looks at the logistics industry and waterborne commerce in both economies. Innovations in container shipping are discussed as it might apply to coastal and inland water transport as well as short sea shipping in the Yellow Sea Region. In applying the Pentaport model and short sea shipping innovations, Incheon's situation with regard to its location (site) being central to trade among China, Japan, North Korea, and Russia could be greatly enhanced. $^{5}$

\section{LOGISTICS AND RELATED SERVICES IN NE ASIA}

Logistic management can be defined as, "the science of balancing the storage (stocks) and movement (flows) of inputs and outputs to meet demand, and minimize

\footnotetext{
${ }^{3}$ Korea Times 2002/02/03

${ }^{4}$ Ibid.

${ }^{5}$ Browning, Jess, "Development of Logistics and Transportation Systems in Promoting Trade \& Economic Growth: Comparing Incheon and Seattle Areas," Korean Observer, Forthcoming Autumn 2003. The author discusses the geographical concepts of SITE and SITUATION and describes the Pentaport model as being able to enhance the Incheon Region's situation with regard to trade in North East Asia.

${ }^{6}$ DOTARS, "Freight Logistics in Australia: an agenda for action," June 2002, p5
} 
total cost while delivering increased efficiencies." Today's internationally competitive businesses work through strategic, integrated global networks that are designed to deliver efficient and high-quality response to demands from anywhere in the world. This trend has given rise to the terms "global logistics" and "supply-chain management." In addition, growing environmental concerns require that logistics should not only be efficient; they should also contribute to sustainable development. ${ }^{7}$ Logistics and value added facilities along with improved intermodal transportation systems can also facilitate increased trade and economic growth within a given urban region. ${ }^{8}$

\section{Korea's Logistics Services}

For a long time, the South Korean Government has regarded the southern ports of Busan and Gwangyang as being primarily important for developing the nation's Northeast Asian Hub policy. Recent rapid economic growth of China and sharp increase in trade however has caused the Korean Government to reassess the importance of Incheon. The high cost and unreliability of logistics in road transport in moving goods and materials north and south has also increased the importance of Incheon in the nation's transport policy.

Incheon is now being developed to attract various foreign business firms and the Port of Incheon is being developed to attract logistics services for marine related trade such as stevedoring, assembly, processing, and packaging as well as other services. On the air cargo side, Incheon International Airport is being developed to boost a range of logistics businesses, notably stevedoring, transportation, warehousing, display, marketing, processing, parts supply, repair, finance and insurance. The Government of the Republic of South Korea is working to develop Korea's human resource capacity in both logistics and business by developing the population's multilingual capabilities. The Ministry of Economy and Finance plans to make living conditions better for foreign residents by building schools, including five international schools, and three satellite campuses of foreign universities. Incheon University will move to Songdo New Town to support capacity building within the new Free Economic Zone. Inha University, which has the Graduate School of International Trade and Logistics as well as a new Center for Global Logistics Studies, opened the Asia-Pacific School of Logistics, funded by Ministry of Education and Human Resources.

\section{China's Logistics Services}

China's Central and Provincial Governments have realized that the development

\footnotetext{
' OECD Organization for Economic Co-operation and Development, Abstract: Source Industry, Services \& Trade, August 2002.

${ }^{8}$ Browning, Jess, "Development of Logistics and Transportation Systems in Promoting Trade \& Economic Growth: Comparing Incheon and Seattle Areas," Korean Observer, Forthcoming Autumn 2003.
} 
of logistics infrastructure and education in logistics is of paramount importance in maintaining the growth that is expected to continue now that China is a member of the World Trade Organization. To date, most of the logistics providers in China have built extensive domestic networks and all have plans for future expansion. In a recent study, many of those surveyed in China stated that they offer total logistics solutions as well as traditional logistics services. They viewed one-stop and value added services as key ingredients to survival in the future, however, traditional services such as freight forwarding, transportation, warehousing and distribution accounted for most of their revenues. Road transportation is the preferred mode of transportation and the majority of those surveyed are out-sourcing it, but retain control over operations. The survey also stated that warehousing is in an early stage of development with rudimentary facilities and limited use of modern information technology. ${ }^{9}$

\section{MARITIME TRADE IN NE ASIA: THE CASE OF KOREA AND CHINA}

This paper deals for the most part with water borne container trade within and between China and Korea although other modes are mentioned. Larger ships with faster discharge rates place increased stress on the land transport connections, and generate a need for faster and more efficient intermodal transfers. The demand for better port performance and increased investment in port facilities has led to changes in many economies port policies. As a result there is a change in port/carrier relations. Traditionally ports served mostly local trade and marine carriers came to ports to pickup the cargo. Under an emerging model, shipping lines serve regional, largely non-local trade, and the cargo is moved by feeder or intermodal service to the ship. ${ }^{10}$ As trade increases shipping lines desire to move to economies of scale with larger ships serving fewer numbers of ports creating load-centers. This puts ports and regions in competition to serve the larger vessels. Fewer ports serving these vessels places more demand on the landside transportation system to move containers to and from these load-centers. It also presents opportunities for developments in coastal and inland shipping.

\section{Container Shipping Between Korea \& China}

The major Chinese ports for trade between China and Korea are the ports of Tiajin, Qingdao, Shanghai, and Dalian. In Korea, the major container lines are calling at the ports of Busan and Gwangyang, while the car-ferry and general cargo ships are

\footnotetext{
' Jim Dai, Shi-Jie Deng, Jihong Ou, Kwok-Leung Tsui, Yang Wang, Huiwen Zhang, Wang Derong, Liu Xiaohong and Li Rui "China Logistics Provider Survey," The Logistics Institute, National University of Singapore, January 2003.

${ }^{10}$ UN/ESCAP, "Regional Shipping and Port Development Strategies Under a Changing Maritime Environment," Maritime Policy Planning Model, 2001.
} 
calling at Busan, Incheon and Pyungtaek. Figure 2 shows the relationship and location of China and Korea ports. Figure 3 shows changes in scheduled waterborne container shipping linking Chinese ports to East Asian countries and their own independently administrated regions. Links to all East Asia economies have been increasing except during the period of the financial downturn. Recently, multi-country routes have increased faster than between China and other East Asia countries. All of these links indicate the "site and situation relationship" that East Asia countries have in trade with various ports of China.

Figure 2. Inland Ports, Rivers \& Coastal Ports in the Yangtze - Yellow Sea Region

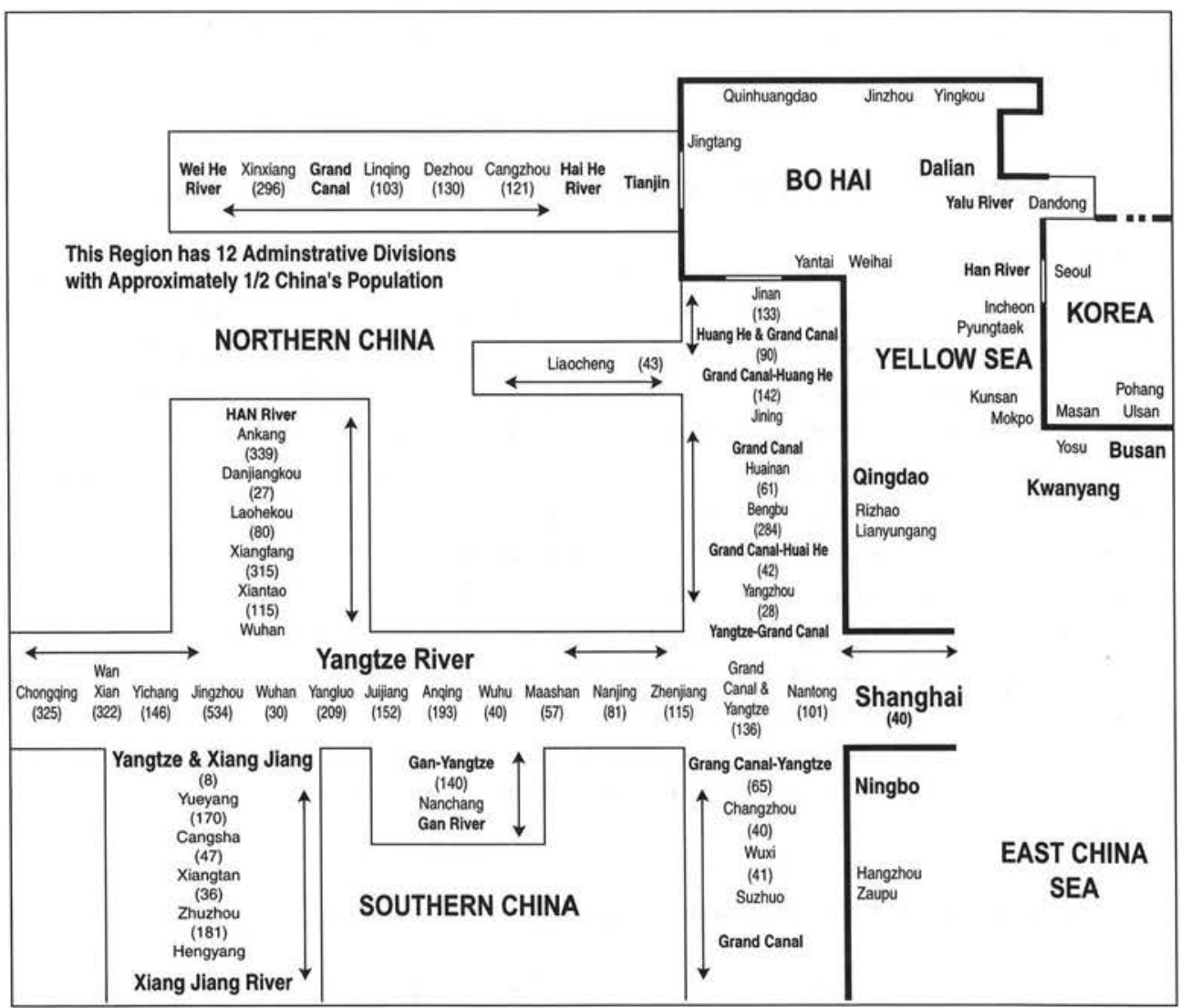

Source : Jess Browning, Journal of International Logistics and Trade, Volume 1, Number 1, December 2003 
There are no 31-46 pages in the printed journal. At the end of the file, an additional unedited original file was attached. 
There are no 31-46 pages in the printed journal. At the end of the file, an additional unedited original file was attached. 
Figure 12. A FLO/FLO Type Yacht Carrier

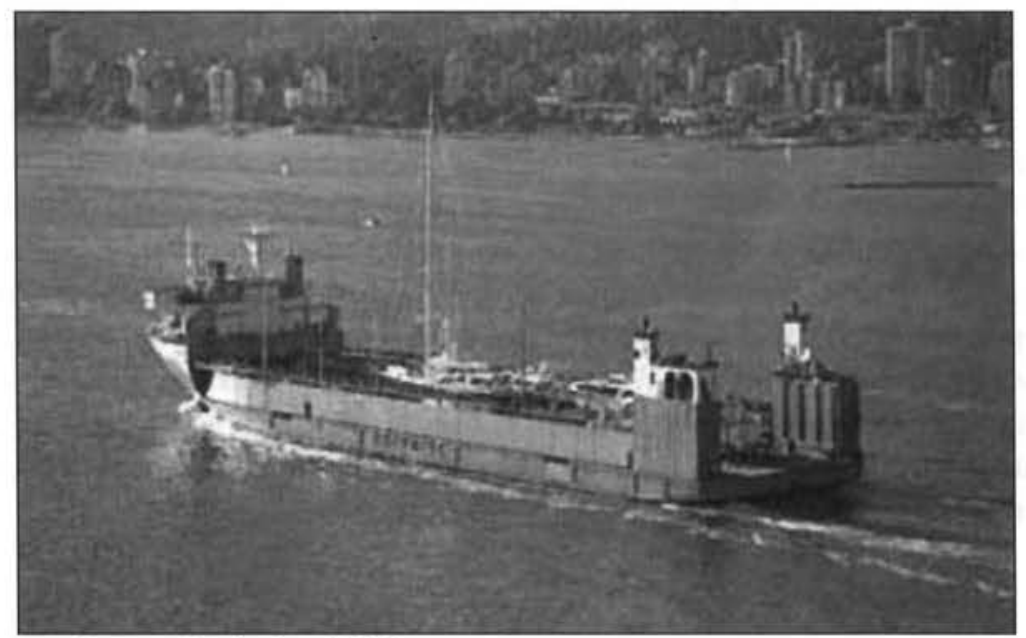

Source : Dockwise (2003)

The rear loading, trapezoidal-hull barge carrier is designed as a "mother ship" for multiples of float-on / float-off barges. For the largest type mother ship, 6 barges can be designed to handle up to 2,000 TEUs each for a total of 12,000 TEUs. Either large or small, the barges are capable of accommodating containers as well as RO/RO cargoes and bulks. It is possible for the larger mother ship make a transoceanic voyage with a combination of all these different cargoes.

In either case, a FLO/FLO mother ship makes it possible for a port to handle increased capacity without investing in deep channels. The barge carrier can discharge and reload its barges in deep water outside the main port area. Essentially, the mother ship arrives in a sheltered area of a load center port and ballasts down allowing the barges to discharge and/or load by floating on and off the vessel. Tugs tow the barges to marine terminals in the hub port or to ports on inland waterways and are then stevedored as conventionally. The larger barges require only 6 to 9 meters of water, well within the capabilities of most of today's container ports and many inland waterways. The smaller barges can be built with a draft depth to operate in the waterways they are designed to serve. It is important to note that the barges can be dispersed among several terminal facilities to make better use of the port facilities and avoid road congestion as well as rail congestion. Unloading and loading of the barges can take place at a more leisure pace during regular working hours, thus avoiding high overtime expense.

\section{The FLO/FLO Vessel as a Floating Transshipment Terminal}

In the case of short sea shipping either for direct shipment or transshipment to out ports 400 to 1000 miles from coastal and inland waterway staging areas, a smaller mother ship would be used that could carry multiples of smaller barges. In the case of 
ocean service vessels, a larger mother ship would be used to take advantage of economies of scale. Both types of vessels, large and small can be designed with an on board crane mounted on side rails to shift containers from one barge to another while underway maximizing loading efficiencies. The loaded barges can be built with cells to prevent side to side movement of containers. They can be un-stacked from one barge and restacked on another for discharge at the next port of call. This would simplify the logistics of loading containers at an inland port on a barge that would be making several stops in direct trade or feeder trade. The mother ship in essence would become a floating terminal similar to that reported in a study on maritime technologies for intermodal transport. ${ }^{40}$ This stern-loading FLO/FLO designed vessel would be able to perform a transshipment function while underway in calm seas or in a sheltered area arriving at a river mouth, a coastal port, or a hub port with the right combination of containers on a barge that would be floated off and replaced with another in a matter of minutes or, at most, a few hours.

\section{Short Sea Shipping}

The Yellow Sea transportation system should be developed as an intermodal short sea shipping system combining various modes such as sea, air, road, rail and inland waterway to achieve competitiveness. It has been pointed out above that research on several engineering problems should be performed to successfully implement the Yellow Sea transportation system. A fast transportation requires rapid cargo transfer from one mode to another to minimize the interruption in cargo flow (see Figure 13). Port time has to be minimized by employing ships with excellent maneuverability, customized automatic docking systems and improved inter-modal terminals.

Figure 13. Fast Cargo Handling System

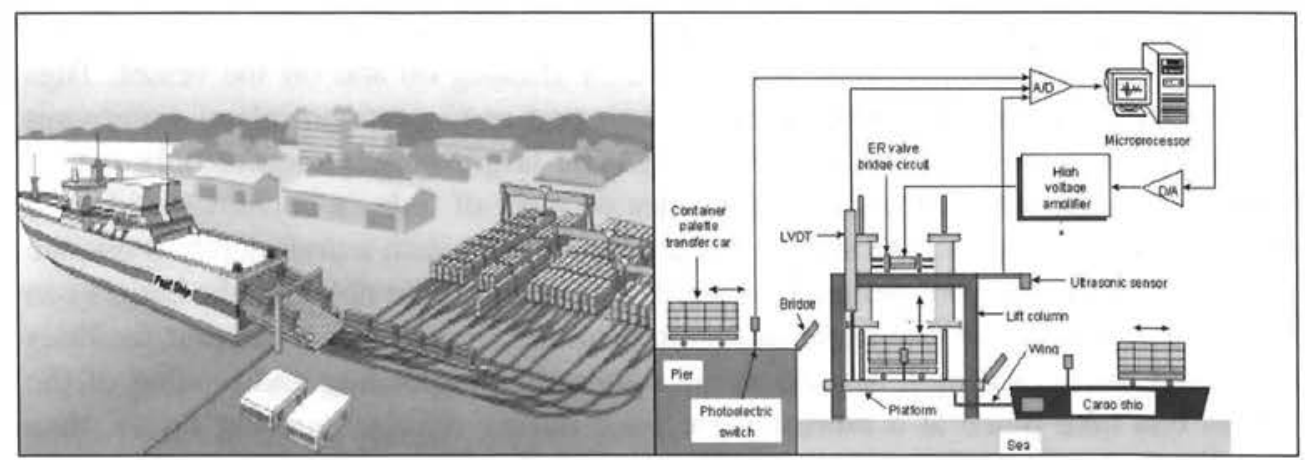

Source : Fast Ship (left), CTYS (right)

${ }^{40}$ Peterlini, Edoardo, "Innovative Technologies for Intermodal Transfer Points," European Union, Marine Technologies for Marine Transport, Competitive and Sustainable Growth Programme, June 2001 
Ships are the most important element for the Yellow transportation system and the roles of the fast ships in the short sea shipping are increasing rapidly. The operating speed of a ship should be chosen to meet the needs of the specific route it serves. Short sea shipping in the Yellow Sea region may require fast ships to compete with land modes such as rail or road. Sea-air mode also need fast ships to transfer cargoes rapidly between regional and hub airport (see Figures 13\&14). The fast ships will mostly handle containers and $\mathrm{RO} / \mathrm{RO}$ trades as well as the passengers since there is no need for bulk cargoes to move fast by sea. Types and principal dimensions of the ships should be chosen to be suitable for the specific routes and the ship has to be designed to allow fast cargo handling. The excellent maneuvering capabilities and stabilities are required for the ships to minimize the port time. The ships may have a capability to economically collect cargoes from several ports in a voyage. Ships for connection of inland waterways to the Yellow Sea will further enhance competitiveness of the Yellow Sea transportation system. Development of sea-river going container ships and barge systems for coastal as well as inland waterways can enhance trade among the countries in the region.

Figure 14. Ships for Short Sea Shipping; New and Old Technologies; Slow and Fast

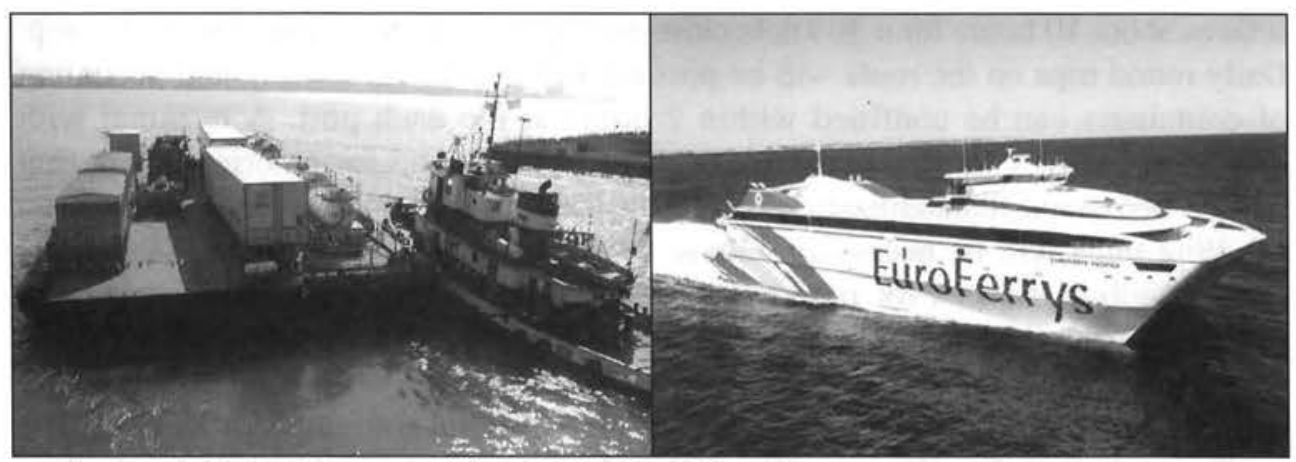

Source : J. T. Lee, Pentaport project 2003, Inha University

The ports on the coast of the Yellow sea suffer from large tidal differences. For example, the tidal differences in Incheon area exceeds 9.7 meter and this will considerably retard fast turn around of the ships. Terminals for short sea shipping have no need to be located in the existing ports. Considerable cost and time will be saved if the terminals are located at the vicinity of a distribution center and transshipment also can be carried out outside a port by exploiting floating terminal technologies. Figure 15 shows artists perception of the floating terminals. 
Figure 15. Floating Terminals

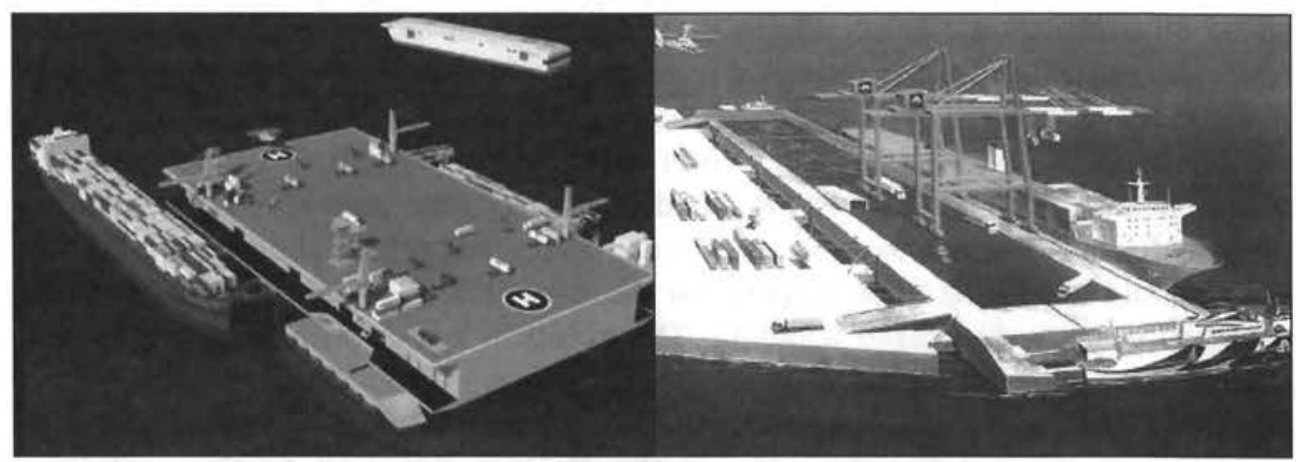

Source : J. T. Lee, Pentaport project 2003, Inha University

The time required for loading and unloading cargo takes a significant portion of the total operating time in short sea shipping and terminals for the fast ships and the design of fast cargo handling systems to minimize port time should be undertaken and implemented. For example, Incheon and Dalian are only 288 nautical miles apart and it takes about 10 hours for a 30 knots class high speed container ship to make the trip. Daily round trips on the route will be possible if port time for loading and unloading of containers can be confined within 2 hours at the each port. A terminal with dedicated facilities for quick and smart cargo handling and for mooring of the ship will be necessary. Standardization of port facilities and equipments as well as cargo handling units will be necessary. Figure 13 shows schematic diagrams of the fast cargo handling systems for reduction of loading/unloading times and to overcome tidal differences (see right picture in Figures 13-15).

Support for the Yellow Sea transportation system will depend on collaboration between Korea and China. The organization of a bilateral committee or Korea-China forum for Yellow Sea Transportation in order to promote cooperation of the two countries in utilizing a Yellow Sea transportation system could go along way to enhancing the mutual understanding and the highly beneficial development of short sea shipping to both countries. Members of any such forum should consist of high rank bureaucrats, scholars, researchers and businessmen from various fields. Support from commercial and industrial sectors and collaboration with researchers will be also essential for the success of the system since commercialization is one of the most important factors in its development. ${ }^{41}$

"Lee, Jae Wook and Lee, Seung-Hee, "On the Transportation System of the Yellow Sea in the 21" Century", ICET 2000, Chinese Academy of Engineering, Beijing, China, October 2000 


\section{SUMMARY AND CONCLUSION}

This paper has explored what the Incheon Region has been, and is doing to create, expand, and improve value-added logistics facilities as well as integrate their intermodal transportation systems in order to enhance their position as a regional hub. It has looked at how Northeast Asia trade flows might be enhanced in the Incheon region by application of the Pentaport model with respect to logistics related services and transportation systems in China and Korea as well as the need for more education and training of professionals in the logistics field. It has looked at water transportation in China, its potential for growth and the need to overcome its obstacles. It has proposed an integrated transportation system for the Yellow Sea region being beneficial to the economies of the Northeast Asia. It has been stressed that innovative technologies for ships, terminals and cargo handling systems should be introduced to realize competitive short sea shipping system in the region. Cooperation among the regional countries will be essential to achieve the final goal. Finally, it has explored the potential of new methods of container shipping and how it could serve inland water transport and short sea shipping in the Yellow Sea Region as related to the pentaport model.

The maritime industry is facing a crisis - the shipping container has enabled the world to trade commodities on a scale that was unimaginable just a few decades ago. In order to accommodate the increase in container volumes moving in and out of marine ports there has to be alternative to existing methods. Fast RO/RO ships and the FLO/FLO barge carrier system should be considered for short sea shipping and inland water transport as well as ocean shipping in addressing logistics problems and the needs of ports, shippers, carriers, and the consumer. Serious consideration should be given to government-sponsored research, in the context of the Pentaport model, leading to the development and application of enhanced vessels such as the FLO/FLO (including the floating terminal type) for transport of inland waterway container barges on short sea shipping routes in Northeast Asia. Full utilization of inland waterways in Korea is inevitable and infrastructures for the purpose need to be constructed. In this sense, resumption of the discontinued Kyung-In canal project will be necessary to connect Han River and the Yellow Sea. This effort would greatly enhance Korea's situation with respect to container shipping on the Yellow Sea and becoming the logistics and business hub of the broader region.

Research on the above engineering topics, as well as political and economical assessments on the Yellow Sea transportation system will be necessary. The cooperation among countries in the region is the most urgent and important for establishment of the Yellow Sea transportation system. An organization of a bilateral consortium for promotion of the Yellow Sea Transportation system is recommended such as the "Korea-China or China-Korea Yellow Sea Forum." Such a forum would enhance and promote intergovernmental cooperation on policy-making and regulation as well as the cooperation among the research institutions and industries of the both countries. 


\section{REFERENCES}

Browning, Jess, "Development of Logistics and Transportation Systems in Promoting Trade \& Economic Growth: Comparing Incheon and Seattle Areas," Korean Observer, Vol. 34, No. 3, Autumn 2003.

Browning, Jess (Ed.), "The Jumbo Barge Carrier: An Ocean Transportation System for the Twenty-First Century," A monograph and working paper, (July 2003) compiled in part from discussions with Bengt Tornqvist who patented the system in March 1998.

Chang, Young-Tae," Korea's Strategic Plan to be Northeast Asia's Logistics Hub:

Chang, Young Tae, "Towards the Pentaport Approach," A Working Paper, Inha University Workshop, October 2003.

China (The World Fact Book) January 1, 2003

Chin-Soo Lim, "Study on Container Throughput Forecasting for Shipping and Port Development Strategies in the APEC region," A Project Proposal by the Shipping, Logistics and Port Research Center, Korea Maritime Institute (KMI), Presented to the Port Experts Group at the $22^{\text {nd }}$ meeting of the APEC Transportation Working Group in Busan, Korea (September, 2003).

Cho, Lee-Jay and Kim, Yoon Hyung, (eds.), "Building an Integrated Transport Market for China, Japan, and Korea: Elimination of Barriers," The Korea Transport Institute and the East-West Center, 2002

Donald Urquhart Shipping News, Business Times, June 24, 2003.

DOTARS, "Freight Logistics in Australia: an agenda for action," June 2002, p5

Jim Dai, Shi-Jie Deng, Jihong Ou, Kwok-Leung Tsui, Yang Wang, Huiwen Zhang, Wang Derong, Liu Xiaohong and Li Rui "China Logistics Provider Survey," The Logistics Institute, National University of Singapore, January 2003.

The World Fact Book, Korea, January 1, 2003

Korea Times 2002/02/03

Lee, Jae Wook and Lee, Seung-Hee. et al, "On the fast sea transportation system for Incheon \& Yongjong Islands (Incheon International airport)", Report, Incheon Metropolitan City, 1999

Lee, Jae Wook and Lee, Seung-Hee, "On the Transportation System of the Yellow Sea in the $21^{\text {st }}$ Century", ICET 2000, Chinese Academy of Engineering, Beijing, China, October 2000

OECD Organization for Economic Co-operation and Development, Abstract: Source Industry, Services \& Trade, August 2002.

Peterlini, Edoardo, "Innovative Technologies for Intermodal Transfer Points," European Union, Marine Technologies for Marine Transport, Competitive and Sustainable Growth Programme, June 2001 
Schwarz, J. "Inland Navigation Concerted Action: State Of The Art Report," Hamburg: INCATS, European Commission, VII, December 1997.

Schinas, O.D., Paraftis, H.N.,'New frontiers through short sea shipping", SNAME Transactions, Vol.105, 1997

Spear, Andrea; Nailer, Chris; and He Susan, China Infrastructure: Sectoral Plans, Reforms and Financing, East Asia Analytical Unit, Department of Foreign Affairs and Trade, Australia, Briefing Paper Series No.6, JULY 1997.

U.S. Department of Energy titled "Innovative/Alternative Transport Modes for Movement of U.S. Coal Exports to the Asian Pacific Basin”, March of 1990.

UN/ESCAP, "Regional Shipping and Port Development Strategies Under a Changing Maritime Environment," Maritime Policy Planning Model, 2001.

Wang,Yang, "China Logistics: Past, Present and Future," Atlanta: Georgia Institute of Technology, 2002.

West Coast Sailors, Volume LXV No. 2, February 22, 2002.

Wu Ming, "Blueprint for Transportation Sector: China Opens Transportation Sector (2001/08/15)" http://www.chinese-embassy.org.uk/eng/16913.html. 


\title{
Short Sea Shipping and Innovations for Intermodal Container Logistics in Northeast Asia
}

\author{
Jess Browning* and Seung-Hee Lee
}

\begin{abstract}
The Incheon Region has numerous assets that fall within a Pentaport model. ${ }^{1}$ These include the Incheon International Airport, the Port of Incheon, a coastal industrial park, free economic zones, a leisure port, and Songdo new town designed to be the future Silicon Valley of Korea. This paper looks at how Northeast Asia trade flows between China and Korea might be enhanced by application of the Pentaport model in making the Incheon region a North East Asian Hub. It looks also at their trade and logistics systems as well as their water borne commerce. It proposes an integrated transportation system for the Yellow Sea Region being beneficial to the economies of the Northeast Asia. It also stresses that innovative technologies for ships, terminals and cargo handling systems should be introduced to develop a competitive short sea shipping system in the region and cooperation among the regional countries will be essential to achieve the final goal. The potential of methods of container shipping is discussed as it might apply to short sea shipping in the Yellow Sea Region that could greatly facilitate Incheon's situation with respect to the broader region in application of the Pentaport model.
\end{abstract}

Keywords: trade and logistics, water borne commerce, short sea shipping, container shipping, and innovative ship, terminal and cargo handling technologies

\footnotetext{
* Jess Browning is Director Emeritus, Global Trade, Transportation, and Logistics Studies and Affiliate Professor, Civil \& Environmental Engineering, the University of Washington, Seattle, WA 98195-3550, USA. Email: jessb@u.washington.edu. Ph. D in Economic Geography, University of Washington. Most recent publication is "A Comparative Study of Management Methods (Construction, Control, and Operation) in U.S. and Japan Container Ports”, Tokyo: Japan Water Front Journal (Bollard Nippon), March 2000.

** Seung-Hee Lee is Professor of School of Mechanical Engineering and the Research Center for Transportation System of Yellow Sea (CTYS) at Inha University, Incheon, 402-751, Korea. E-mail: shlee@inha.ac.kr Ph. D in Ocean Engineering, Massachusetts Institute of Technology

${ }^{1}$ Pentaport is a concept announced in the 'Ocean Korea 21' initiative of the Ministry of Maritime Affairs and Fishery, Korea in May 2000. The concept has been refined at Inha University for regional economic development that brings together a cluster of various services in the context of 5 ports - a business port, a techno port, leisure port, airports and sea port (2003).
} 
Page 2

\section{BACKGROUND}

Incheon is poised to be the business and logistics hub of Northeast Asia. It is endowed with what is termed invaluable pentaport assets which consists of five ports in one: Incheon International Airport, Incheon seaport, plus a leisure port, a teleport (telecommunications), and a business port. Incheon International Airport has been designed to be the hub airport of Asia; the Port of Incheon, serves as the gate to the Seoul Metropolitan area and central provinces from the Yellow Sea region. As shown in Figure 1, the region is comprised of three free economic zones including a coastal industrial park, a customs free zone locating a logistics park, and the new Songdo town which is destined to be the future business hub of Northeast Asia, namely the Venice in the Orient. ${ }^{2}$ Universities in Incheon provide the academic and educational infrastructure to meet the needs of these geographical and other conditions, thereby make it possible to be a center of higher education in the Northeast Asian Region.

>>> Insert Figure $1<<<<$

The Republic of South Korea and its Incheon area are progressing towards becoming a Northeast Asian economic hub as a result of long range planning by government leaders. This necessitates establishment of an efficient logistics system and includes providing more container berths to handle increased traffic in both containerized cargo and steel between the south coast and Seoul area as well as providing increased capacity to meet the demand for vessels carrying containerized cargo between Korea and other Northeast Asian destinations. Developments around Incheon are also proposed and

\footnotetext{
${ }^{2}$ Charm City, Newsweek international, Atlantic Edition, 2004/03/29
} 
Page 3

intended to meet growing Northeast Asian trade and coastal shipping with cargoes destined for the Seoul area and the large Busan container port to the southeast. ${ }^{3}$

The Incheon region will increasingly become a true hub of commerce as developments continue in the creation of logistics, value-added, and distribution facilities along with improved intermodal linkages to enable passengers and freight to move from one mode to another seamlessly, as well as improve its communications and information networks. It requires giving support to foreign companies and foreign investors that want to do business in the region. This is being done in part by designating the free economic zones and by expanding economic cooperation in Northeast Asia, with China and Japan as crucial partners. ${ }^{4}$ The development of better coastal and short sea shipping as well as inland water transport is a critical element in application of the Pentaport model in Incheon area with respect to marine trade and logistics services including education.

This paper looks at how Northeast Asia trade flows between China and Korea might be enhanced by application of the Pentaport model in making the Incheon region a Northeast Asian Hub with respect to development of logistics related services and regional transportation systems. It also looks at the logistics industry and waterborne commerce in both economies. Innovations in container shipping are discussed as it might apply to coastal and inland water transport as well as short sea shipping in the Yellow Sea Region. In applying the Pentaport model and short sea shipping innovations, Incheon's situation with regard to its location (site) being central to trade among China, Japan, North Korea, and Russia could be greatly enhanced. ${ }^{5}$

\footnotetext{
3 Korea Times 2002/02/03

4 Ibid.

5 Browning, Jess, "Development of Logistics and Transportation Systems in Promoting Trade \& Economic Growth: Comparing Incheon and Seattle Areas,” Korean Observer, Forthcoming Autumn 2003. The author discusses the geographical concepts of SITE and SITUATION and describes the Pentaport model as being able to enhance the Incheon Region's situation with regard to trade in North East Asia.
} 


\section{LOGISTICS AND RELATED SERVICES IN NE ASIA}

Logistic management can be defined as, "the science of balancing the storage (stocks) and movement (flows) of inputs and outputs to meet demand, and minimize total cost while delivering increased efficiencies." ${ }^{6}$ Today's internationally competitive businesses work through strategic, integrated global networks that are designed to deliver efficient and highquality response to demands from anywhere in the world. This trend has given rise to the terms "global logistics" and "supply-chain management." In addition, growing environmental concerns require that logistics should not only be efficient; they should also contribute to sustainable development. ${ }^{7}$ Logistics and value added facilities along with improved intermodal transportation systems can also facilitate increased trade and economic growth within a given urban region. ${ }^{8}$

\section{Korea's Logistics Services}

For a long time, the South Korean Government has regarded the southern ports of Busan and Gwangyang as being primarily important for developing the nation’s Northeast Asian Hub policy. Recent rapid economic growth of China and sharp increase in trade however has caused the Korean Government to reassess the importance of Incheon. The high cost and unreliability of logistics in road transport in moving goods and materials north and south has also increased the importance of Incheon in the nation's transport policy.

Incheon is now being developed to attract various foreign business firms and the Port of Incheon is being developed to attract logistics services for marine related trade such as stevedoring, assembly, processing, and packaging as well as other services. On the air cargo side, Incheon International Airport is being developed to boost a range of logistics

\footnotetext{
${ }^{6}$ DOTARS, “Freight Logistics in Australia: an agenda for action,” June 2002, p5

7 OECD Organization for Economic Co-operation and Development, Abstract: Source Industry, Services \& Trade, August 2002.

${ }^{8}$ Browning, Jess, "Development of Logistics and Transportation Systems in Promoting Trade \& Economic Growth: Comparing Incheon and Seattle Areas,” Korean Observer, Forthcoming Autumn 2003.
} 
businesses, notably stevedoring, transportation, warehousing, display, marketing, processing, parts supply, repair, finance and insurance. The Government of the Republic of South Korea is working to develop Korea's human resource capacity in both logistics and business by developing the population's multilingual capabilities. The Ministry of Economy and Finance plans to make living conditions better for foreign residents by building schools, including five international schools, and three satellite campuses of foreign universities. Incheon University will move to Songdo New Town to support capacity building within the new Free Economic Zone. Inha University, which has the Graduate School of International Trade and Logistics as well as a new Center for Global Logistics Studies, opened the Asia-Pacific School of Logistics, funded by Ministry of Education and Human Resources.

\section{China's Logistics Services}

China's Central and Provincial Governments have realized that the development of logistics infrastructure and education in logistics is of paramount importance in maintaining the growth that is expected to continue now that China is a member of the World Trade Organization. To date, most of the logistics providers in China have built extensive domestic networks and all have plans for future expansion. In a recent study, many of those surveyed in China stated that they offer total logistics solutions as well as traditional logistics services. They viewed one-stop and value added services as key ingredients to survival in the future, however, traditional services such as freight forwarding, transportation, warehousing and distribution accounted for most of their revenues. Road transportation is the preferred mode of transportation and the majority of those surveyed are out-sourcing it, but retain control over operations. The survey also stated that warehousing 
is in an early stage of development with rudimentary facilities and limited use of modern information technology. ${ }^{9}$

\section{MARITIME TRADE IN NE ASIA: THE CASE OF KOREA AND CHINA}

This paper deals for the most part with water borne container trade within and between China and Korea although other modes are mentioned. Larger ships with faster discharge rates place increased stress on the land transport connections, and generate a need for faster and more efficient intermodal transfers. The demand for better port performance and increased investment in port facilities has led to changes in many economies port policies. As a result there is a change in port/carrier relations. Traditionally ports served mostly local trade and marine carriers came to ports to pickup the cargo. Under an emerging model, shipping lines serve regional, largely non-local trade, and the cargo is moved by feeder or intermodal service to the ship. ${ }^{10}$ As trade increases shipping lines desire to move to economies of scale with larger ships serving fewer numbers of ports creating load-centers. This puts ports and regions in competition to serve the larger vessels. Fewer ports serving these vessels places more demand on the landside transportation system to move containers to and from these load-centers. It also presents opportunities for developments in coastal and inland shipping.

\section{Container Shipping Between Korea \& China}

The major Chinese ports for trade between China and Korea are the ports of Tiajin, Qingdao, Shanghai, and Dalian. In Korea, the major container lines are calling at the ports of Busan and Gwangyang, while the car-ferry and general cargo ships are calling at Busan, Incheon and Pyungtaek. Figure 2 shows the relationship and location of China and Korea

9 Jim Dai, Shi-Jie Deng, Jihong Ou, Kwok-Leung Tsui, Yang Wang, Huiwen Zhang, Wang Derong, Liu Xiaohong and Li Rui "China Logistics Provider Survey," The Logistics Institute, National University of Singapore, January 2003.

10 UN/ESCAP, "Regional Shipping and Port Development Strategies Under a Changing Maritime Environment,” Maritime Policy Planning Model, 2001. 
ports. Figure 3 shows changes in scheduled waterborne container shipping linking Chinese ports to East Asian countries and their own independently administrated regions. Links to all East Asia economies have been increasing except during the period of the financial downturn. Recently, multi-country routes have increased faster than between China and other East Asia countries. All of these links indicate the "site and situation relationship" that East Asia countries have in trade with various ports of China.

$>>>$ Insert figure $2<<<<$

$>>>$ Insert Figure $3<<<<<$

A recent study ${ }^{11}$ stated that "Korea and Japan are competing for transshipment hub ports to deal with the ocean-going containers, from China to USA.” It also stated that "In comparing shipping between China-Korea and China-Japan, since 1994, the division of short-sea services and ocean-going services has changed from 60:40, to 50:50, and then 30:70, indicating that Korean ports (primarily Busan) are becoming transshipment hubs in the region for China’s export cargo.” Figure 4 shows this changing relationship in the ratio of types of container service between China and East Asia economies, for the year 2000. The ratio of links to Korea and Japan from the 4 major Northern Chinese ports in regional and world-wide trade is shown in Figure 5 and indicates that short sea shipping between China and Korea with the exception of Japan is much greater than ocean shipping between China and Other world regions. ${ }^{12}$

\footnotetext{
${ }^{11}$ Cho, Lee-Jay and Kim, Yoon Hyung, (eds.), "Building an Integrated Transport Market for China, Japan, and Korea: Elimination of Barriers,” The Korea Transport Institute and the East-West Center, 2002

${ }^{12}$ Note: Short Sea Shipping can be both direct shipment as well as feeder service for transshipment which may be for either ocean service or back into the short sea shipping system depending upon the regulation environment.
} 
>>>>Insert figure $4<<<<$

>>>>Insert Figure $5<<<<<$

While world container volumes are increasing at a very rapid pace, it can be seen in Figure 6 that Asia trade is far ahead of the other world regions. In its recent research report UBS said that the container demand forecast in Asia for 2003 was growing by 6.8 percent and for 2004 by 7 percent. This amounts to a total global container trade of 75 million TEUs this year and 80 million TEUs in 2004. For 2005, UBS is forecasting a 6.3 per cent growth to 86 million TEUs. ${ }^{13}$

\section{World Container Trade}

In consideration of container trade volumes in North East Asia, in the context of the Pentaport model, the prospects are very favorable. Today the economies encompassed by the Asian Pacific Economic Cooperation (APEC) forum account for $50 \%$ of world trade and $65 \%$ of world gross domestic product (GDP) and, therefore, provide the economic backbone of the contemporary world. Northeast Asia is the core growth engine as the region contributed $17 \%$ to world GDP in 2000 with the expectation of 30\% in 2010.” ${ }^{14}$

In the last decade, Asia has undergone tremendous structural change brought on by new markets and new technologies leading to great increases in trade as indicated in Figure 6. New container ships are calling at a broad network of hub and feeder ports that require an increase in capacity. Technological change and the trend toward larger and faster vessels

\footnotetext{
13 Donald Urquhart Shipping News, Business Times June 24, 2003.

14 Chang, Young-Tae,” Korea's Strategic Plan to be Northeast Asia's Logistics Hub: Towards the Pentaport Approach,” A Working Paper, Inha University Workshop, October 2003.
} 
Page 9

is also putting demand on marine ports for newer and larger equipment as well as new data management systems and procedures. ${ }^{15}$

$>>>$ Insert figure $6<<<<$

\section{WATER TRANSPORTATION IN KOREA AND CHINA}

The map in Figure 2 shows the Yellow Sea Region, its ports and inland waterways. The map also shows the extent of inland water transport and indicates a potential for greater short sea shipping within the region. Water transport by both coastal and inland waterways has tremendous potential for reducing both road and rail congestion as well as contributing to a more efficient and environmentally friendly system.

\section{Transportation Modal Splits in China and Korea}

In both China and Korea, there is heavy dependence on roads to move cargo causing congestion, pollution and other environmental problems. The modal split for the total freight volume in Korea (2002) was road transport 76.0\%, railway 5.9\%, and coastal shipping 19.4\%. “To resolve the problems related dependence on roads for cargo transport, the government is seeking to increase coastal shipping's proportion of the domestic transportation of containers."16 However, the proportion of coastal shipping in the domestic transportation is continuously decreasing and coastal shipping occupied only $0.8 \%$ of the domestic containers processed at Busan in 2002. ${ }^{17}$ In China the road is also the favored transportation mode. It accounts for $62 \%$ of the total transportation in terms of volume of

\footnotetext{
${ }^{15}$ Chin-Soo Lim, "Study on Container Throughput Forecasting for Shipping and Port Development Strategies in the APEC region,” A Project Proposal by the Shipping, Logistics and Port Research Center, Korea Maritime Institute (KMI), Presented to the Port Experts Group at the $22^{\text {nd }}$ meeting of the APEC Transportation Working Group in Busan, Korea (September, 2003).

16 Chang, Young-Tae,” Korea’s Strategic Plan to be Northeast Asia’s Logistics Hub: Towards the Pentaport Approach,” A Working Paper, Inha University Workshop, October 2003

${ }^{17}$ Department of Maritime Affairs and Fisheries, Korea
} 


\section{Page 10}

goods. Although rail is the second most popular mode, it accounts for only about $15.5 \%$ of transportation. $^{18}$

\section{Korea Ports and Water Transport}

Inland waterways in Korea are underutilized for shipping due to various reasons including national security and poor infrastructures investment. For example, the Han River which has a length of more than $500 \mathrm{~km}$ and its basin area covers more than $10 \%$ of the Korean Peninsular, is the fourth largest river in Korea and passes through the Seoul Metropolitan City. But ship traffic through the river is not currently allowed and the recently proposed construction plan of a canal connecting the Han River and the Yellow Sea is faltering due to strong opposition of NGO’s under the name of environment protection.

Nearly all containerized cargo enters or leaves Korea through the deep-water ports along the south and southeastern coasts. Busan is the largest and handled over 8,070,000 TEUs in 2001 which was $81 \%$ of Korea's total container volume. The ports along the west coast are generally less accessible to large ships. Incheon is the largest west coast port handling mostly bulk commodities and coastal container traffic. Of the 23,700 ship arrivals at Incheon in 1997, 6,000 were by ocean-going vessels whereas Busan had 33,600 arrivals, of which 19,000 were by ocean-going vessels.

There is a large movement of containers between the Seoul area and Busan although, as mentioned earlier, this trade is dominated by road transport. Factors driving Korea port development are national policy level. There is concern over logistics costs that are the principal drivers behind many transport infrastructure developments. These are reflected in the Korean ports sector by providing more container berths; meeting the demand for and increasing the coastal share of traffic in both containerized cargo and steel between south

\footnotetext{
18 Jim Dai, Shi-Jie Deng, Jihong Ou, Kwok-Leung Tsui, Yang Wang, Huiwen Zhang, Wang Derong, Liu Xiaohong and Li Rui “China Logistics Provider Survey,” The Logistics Institute, National University of Singapore, January 2003.
} 


\section{Page 11}

coast and Seoul; and providing increased capacity to meet the demand for vessels carrying containerized cargo between Korea and other northeast Asian destinations. ${ }^{19}$

In the context of the Pentaport model to develop the Incheon Region as a hub of North East Asia, Korea’s Regional Research Center for Transportation System of the Yellow Sea (CTYS) at Inha University is working to improve the region's international competitiveness by developing an appropriate transportation model for the Yellow Sea region as well as a futuristic transportation system connecting Incheon International Airport, Incheon Port, and the Han River. The Center is involved in several related studies that involve short sea shipping. One is to do research for a high-speed vessel that could be used in river shipping of people, goods and material between the Han River and various Korean ports, including Incheon International Airport, as well as shipping on the Yellow Sea among Korea, China, and North Korea. Another related study is the development of a transportation system for sea-river shipping. This is aimed at developing an integrated seariver transportation system to promote economic interaction within East and North East Asia. Included in the Center's efforts will be the development of a sea-river container ship for trips between the Han River in Korea and the Yangtze River (and Han Jiang River) in China. ${ }^{20}$ These topics are also the focus of this paper.

\section{China Ports and Inland Water Transport}

China has 110,000 km (1999) of waterways but only several are navigable by larger vessels. In the North, its main ports and harbors include Dalian, Lianyungang, Nanjing, Nantong, Ningbo, Qingdao, Qinhuangdao, Shanghai, Tianjin, Wenzhou, Xingang, Yantai, and Zhanjiang. ${ }^{21}$ For centuries, boats and ships have played an important role in transporting goods and people on Chinese rivers. These rivers mostly serve east-west routes,

\footnotetext{
19 Korea Times 2002/02/03

20 http://ctys.inha.ac.kr/english/research.htm

${ }^{21}$ China (The World Fact Book) January 1, 2003
} 


\section{Page 12}

while canals and coastal shipping have provided north-south links. Tremendous growth in international trade and rapidly expanding coastal shipping (as an alternative to congested roads and railways) have severely strained China's port infrastructure. The main bottlenecks have been a shortage of deep-water ports, inadequate transport links, handling facilities and capacity at both inland and coastal ports as well as undeveloped (including dredging) river routes and obsolete fleets. The national inland water transport system has been identified as one means of relieving pressure on the overburdened road and rail systems. The centerpiece of planned investments is the proposed renovation and reopening of the Grand Canal linking Beijing with the Yangtze River Delta. ${ }^{22}$

Marine transport in China is divided into two major navigation zones: the northern and the southern ones. This article looks at the northern zone's rivers that empty into the Bo Hai, the Yellow Sea, and the East China Sea. The major inland navigable rivers in Northern China are the Yangtze, the Heilongjiang (in the far northeast), the Huai He, the Han, the Xiang Jiang, the Gan, the Wei He, the Hai He, the Grand Canal between Beijing and Hangzhou, and the Qiantang estuary (see Figure 2). The Yangtze, the "golden waterway" of China's inland river transport, has considerable volume of both freight and passenger transport. Nanjing Harbor, the largest river harbor in China, has an annual capacity of 40 million tons. $^{23}$

The development and operation of transportation infrastructure by foreign investment is encouraged by Chinese government, but a Chinese entity shall have a controlling share or play a leading role in the development and operation of urban metro, public dock and civil airport projects. For international ocean transportation, overseas

\footnotetext{
22 Spear, Andrea; Nailer, Chris; and He Susan, China Infrastructure: Sectoral Plans, Reforms and Financing, East Asia Analytical Unit, Department of Foreign Affairs and Trade, Australia, Briefing Paper Series No.6, JULY 1997. http://www.dfat.gov.au/publications/catalogue/eaaubp6.pdf

23 http://www.asianinfo.org/asianinfo/china/transportation.htm
} 


\section{Page 13}

investors are allowed to set up joint venture shipping company to offer maritime international transportation (passenger and cargo) services, but a Chinese entity shall hold more than $50 \%$ of the registered capital and all vessels shall fly the Chinese flag. For domestic waterway transportation (both river and coastal), overseas investors are allowed to set up water tourist transportation enterprises in China, but cargo service is forbidden. Foreign investors in an agency for international cargo transportation are permitted to establish equity or contractual joint venture in China. ${ }^{24}$

The country's traffic and transportation network is expected to improve and become more efficient during the current five-year State transportation plan. Construction of harbors, inland river transportation routes, railways, roads, airports, and natural gas pipeline rank as top development priorities. ${ }^{25}$

\section{SHORT SEA SHIPPING IN THE YELLOW SEA}

Logistic in the 21st Century is changing rapidly as a result of globalization and is accompanied by localization. As the process unfolds, only a fewer but larger sea and airports will serve as a hub for economic regions with inter-modal transportation networks linking local ports and neighboring hinterlands. It is predictable therefore, that the number of post-Panamax vessels be calling at hub ports will increase but also smaller vessels needed for feeder services among small ports and serving hub ports will also increase. Short sea shipping to compete with land transport mode is also becoming important in many regions to relieve road and rail congestion as well as reduce environmental impacts.

The main scope of this section of the paper is to focus on short sea shipping in the Yellow Sea Region that encompasses the Korean peninsula and northeastern China.

\footnotetext{
24 http://www.itdn.com.cn/english/tradecenter/Financeg02.htm

25 Wu Ming, “Blueprint for Transportation Sector: China Opens Transportation Sector (2001/08/15)” http://www.chinese-embassy.org.uk/eng/16913.html
} 


\section{Page 14}

Development of a transportation system suitable for the Yellow Sea region comprising ships, barges, harbors, cargo handling systems, train ferries, terminals and logistics as well as other related technologies will be very important for economic growth and prosperity in the region.

\section{Incheon and the Yellow Sea Region}

The Yellow Sea region is a great economic engine that has a vast population with major cities and industrial complexes of Korea and China located on or near its coastal areas. For China, the Yellow Sea is a "gateway" as well as a "bridge" to Northeast Asia and to the world. Four "land bridges" for connection of Asia and Europe are already designated in the Yellow Sea Region at Shanghai, Liongungang, Tianjin and Dalian (see Figure 7). The Yellow Sea is also an important water route for Korea in trade with China and Southeast Asia, as well as a water route to connect with railways extending to Europe. It is also an alternate route in moving containers between Busan, Gwangyang and the capital region.

$$
>>>\text { Insert figure } 7<<<<
$$

Incheon Metropolitan City is positioned at the eastern center of the Yellow Sea Region and has a strong hinterland. The city is also located at the central part of the Korean peninsula where South Korea's Capital and major cities are found with more than 30 million people making up almost half of the total Korean population. With its economical and geopolitical advantages, Incheon is in good posture to become a logistics center of the Yellow Sea Region.

\section{Development of Transportation System in Northeast Asia}

With the expectation that Northeast Asia will become the heart of the world's economy in the near future, the three Northeast Asian countries, Korea, China and Japan, pay keen 
attention to development of hub ports. For a port to be a hub requires investment in handling equipment for post-Panamax vessels and other types of sophisticated equipment. Logistical services also need to be improved in order for the shippers, shipping lines, terminal operators and consignees to have an optimal throughput of containers that will reduce overall cost and promote improved intermodal operations ${ }^{26}$. It is necessary therefore to make huge capital investments in order to build hub ports and develop related hardware, software and social overhead capitals (SOC) such as roads, airways, railways and shipping routes for connection of regional ports and hinterlands. Therefore, SOC development is an important factor that deserves careful attention in planning the construction of a hub port or in the collaboration among Northeast Asian countries in transportation.

The present status of sea transportation in Northeast Asia differs by the regions divided by Korean peninsula, the Yellow Sea and the East Sea regions. In the East Sea region, short sea shipping among Korea, Japan and Russia is already active along with the liner shipping to other countries in the world. The shipping in the Yellow Sea region needs more development and recent increased growth in trading volumes among China, Korea, Japan and the Southeast Asian countries should accelerate the process.

The transportation system in the Northeast Asia needs to be developed into an integrated transportation system in which various modes of transportation, including sea, air, rail and road are interconnected to achieve cost efficient and time effective transportation. ${ }^{27}$ Fast vessels may connect the ports with dedicated facilities or feeders of lower speed may connect hub and regional ports inland or on coast. Both ends of the network including road transport need to be used to enable 'door to door' service not only

26 Schinas, O.D., Paraftis, H.N.,”New frontiers through short sea shipping”, SNAME Transactions, Vol.105, 1997

27 Lee, Jae Wook and Lee, Seung-Hee, et al, “On the Fast Sea Transportation System for Incheon \& Yongjong Islands (Inchon International airport)”, Report, Incheon Metropolitan City, 1999 
Page 16

to meet customer's requirements but also to improve competitiveness in, and between, the various transport modes. The rail mode alone is thought by some to be more competitive than the pure sea mode in transporting goods and materials between Northeast Asia and Europe. Improvements in infrastructure still need to be made however, especially to accommodate double-stacked containers, but it is expected that an adequate combination of rail and sea modes can further reduce costs. The four railways in Northeast Asia show in Figure 7 deserve special consideration: TSR (Trans Siberia railroads), TCR (Trans China railroads), TMR (Trans Manzuria railroads) and TKR (Trans Korea railroads).

\section{The Yellow Sea Transportation System}

The distances between the major ports in the Yellow Sea are less than 600 nautical miles and the time required to connect any two ports in the region takes no more than two days for a conventional freighter. Among the routes, Incheon-Yantai and Incheon-Dalian are less than 290 nautical miles away from each other and daily round trips are possible for ships of speed exceeding 25knots (see Figure 8). Transit times and costs should be competitive to land transport if adequate systems are provided, even after South and North Korea agree to connect their roads and railways. Waterborne transportation and ships can relieve road congestion. They are less polluting, demand less infrastructure and have fewer accidents than road transport. It is foreseeable that short sea shipping among regional ports and the connection of hub and regional ports will grow rapidly in the Yellow sea region as it has in the Baltic and North Sea regions. ${ }^{28}$

$$
>>>\text { Insert figure } 8<<<<
$$

\footnotetext{
${ }^{28}$ Lee, Jae Wook and Lee, Seung-Hee, “On the Transportation System of the Yellow Sea in the $21^{\text {st }}$ Century”, ICET 2000, Chinese Academy of Engineering, Beijing, China, October 2000
} 
China has utilized rivers and canals as a major route of inland transportation for hundreds of years. The Great canal was constructed more than fifteen hundred years ago as a major north-south inland waterway. There are many inland harbors in the hinterland of China's waterways in which land transportation systems to the major cities are well developed as shown in Figure 2. Currently the benefit of inland waterway transportation is seriously being considered in Korea as well and the construction of the Kyung-In (SeoulIncheon) canal connecting Yellow Sea and Han River has been already started but is on hold at the present due to opposition by environmentalists NGOs.

Figure 9 shows a conceptual schematic diagram for the Yellow Sea transportation system in the Northeast Asia as it connects to the various land-bridges as shown in Figure 7. Implementation of the system defined above necessitate advances in vessels suitable for Yellow Sea Transportation which will require a fast cargo handling system, floating terminal, train Ro/Ro ferry, software needed for management of vessel and cargo and electronic data interchange to provide “Just-In-Time” and other types of efficient service.

$>>>>$ Insert figure $9<<<<$

\section{Container Barges for Short Sea Shipping}

Containerization of marine cargo along with new technologies has enabled global trade to expand at extremely rapid rates over the past four decades. There is growing concern however, that the shipping industry's method for coping with the growth of container traffic by building bigger ships to achieve greater economies of scale may be reaching its limits.

Consider the following: Between 1965 and 2000, the shipping industry went from zero to 226 million TEUs containers. This was remarkable when looking at the investments in ships, port facilities, and inland transport, port planning, management and labor relations 
Page 18

that were made in order to accommodate the growth. The growth of worldwide container projections indicates a worldwide TEU level of 550 million by 2025.

Traditionally the industry's response to the challenge of container trade growth has been to commission larger containerships of 6,000 and 8,000 TEU which is forcing port communities to deepen channels, devote more land to container operations, build on-dock rail connections and make other investments to remain competitive, especially if they want to become a hub port. The costs are staggering; environmental and land use constraints are impinging on ports ability to make capital investments; and the peak volumes of containers projected to move through ports on and off these mega containerships threaten to increase congestion, and even nullify the efficiencies that the shipping lines are attempting to achieve through these large capacity vessels. ${ }^{29}$

With the emergence of "hub ports" in ocean transportation, there is a growing interest in short sea shipping to move containers between ports both in coastal trade for a given economy and between economies. Concurrent with this is interest in improving the efficiency of moving containers from inland ports to the ocean ports and hub ports via short sea shipping. This has led to renewed interest in the role of barge transportation in inland water transport and short sea shipping for container movements without having to load and unload container ships in the process.

\section{Barges for Coastal and Inland Water Transport}

In the USA, Columbia Coastal Transport is the barge carrier selected by the Port of Albany New York to implement its part in the Port Inland Distribution Network. This program is designed to alleviate port and highway congestion, improve container handling and create

\footnotetext{
${ }^{29}$ Browning, Jess (Ed.), "The Jumbo Barge Carrier: An Ocean Transportation System for the Twenty-First Century,” A monograph and working paper, (July 2003) that was compiled in part from discussions with Tornqvist who patented the system in March 1998.
} 
sustainable environmental benefits by shifting cargo to new inland hub ports using all-water service. The inland hub port concept is not new but is an important development for U.S. ports. The port announcement stated "By shifting cargo volumes to inland hubs, ports are better able to address their mounting concerns about space limitations, improving efficiencies and safeguarding the environment. Essentially, the ports are able to grow and manage imports and exports more efficiently." Columbia Coastal offers full EDI capability along with total logistics planning for pickup and deliveries as part of its inland express service. $^{30}$ Columbia Coastal uses 11 barges on their US East Coast ocean service that extends from the Caribbean to Canada.

In Indonesia, Eng Lee Shipping, which is one of the largest barge operators in the region, has noticed a growing trend among their clients towards containerization. They see it as cost-effective way to ship their goods in the best possible condition and are positioning to meet this trend by building special barges for containers. These barges will be able to ply the small river ports as well as the larger coastal ports such as the one at Jakarta. Eng Lee’s first such container barge is set to be completed by the end of 2003, with three more in the pipeline. $^{31}$

\section{Sizes of Barges for Coastal and Inland Water Transport}

Size is important in consideration of vessel design for coastal and inland water transport not only for volume but also for width, height, and length in order to navigate in the areas designed for service. Columbia Coastal's largest barge has a width of 29 m, length 120 m, and draft $6.4 \mathrm{~m}$. It is 10,000 DWT and has a capacity of 912 TEU containers. Their smallest barge has a width of $22.5 \mathrm{~m}$, length $76 \mathrm{~m}$, and draft $4.5 \mathrm{~m}$. It is 3,300 DWT and has a capacity of 420 TEU containers. The photo in Figure 10 shows one of Columbia Coastal's

\footnotetext{
30 http://www.columbia-coastal.com/

${ }^{31}$ http://www.psa.com.sg/portview/pv0303/pv8.htm
} 
Page 20

barges being towed in transit between ports on the US East Coast. On the West Coast, the Lock at Bonneville Dam (the first lock on the Columbia River system) can accept container barges up to $25 \mathrm{~m}$ wide. The lock is $26 \mathrm{~m}$ wide by $206 \mathrm{~m}$ long. River depth varies with minimum depth (dredged) of $4.3 \mathrm{~m}$. The maximum draft for tugs is $3.7 \mathrm{~m}$. In Europe, the standard size inland waterway barge has a width of $11.4 \mathrm{~m}$, length of 76.5 meters, and draft of 3.7 meters. These barges have a capacity of 102 TEU containers.

$$
\text { >>> Insert figure } 10<<<<
$$

In China, the dimensions of a 5,000 DWT vessel built by Mawei Shipyard, Fuzhou, Fujian for inland water and sea transport has a width of $19 \mathrm{~m}$, length of $109 \mathrm{~m}$, and draft of $7.7 \mathrm{~m}$. It has also built smaller vessels for similar service with a width of $11.6 \mathrm{~m}$, length of 63 meters, and draft of $4.9 \mathrm{~m}$. These sizes indicate draft depth restriction for some of China’s inland waterways.

These various dimension and capacities of barges and vessels in various regions of the world point out the need for close attention to the parameters of a specific inland waterway in the development of its inland water transport. For example, China has 163 ports of these 109 are inland water ports. As noted above, by the end of 2005 China hopes to build and improve 200 inland berths and well as liberalize investment in logistics (transportation, freight forwarding, storage, warehousing) and port management.

\section{Obstacles to Coastal and Inland Water Transport}

There are many obstacles to growth of costal and inland water transport in many economies. The main obstacle is the risk in investing in new ship technology development and construction of new ships, however, the infrastructure of many inland waterways present problems. Many have limited water-depth, width, insufficient lock dimensions and bridge 
heights that restrict the container transport to stacking less than three levels. There are usually insufficient inland container terminals and barge berths, ports are not optimized for transshipment from inland waterways to other modalities resulting in inefficiencies and higher costs. There is also a problem of reliability due to ice during cold winters on some waterways, dry summers resulting in low water depth in rivers and high water after heavy rainfalls. Transshipment in sea ports from ship to ship or from shore to barges is still inefficient, time consuming and expensive in many terminals. Telecommunication and information systems are not sufficiently employed in inland water transport systems. Small shipping enterprises, operating one or two barges are not usually incorporated in cargo management networks and booking is not well developed in order to serve all shippers. ${ }^{32}$ Those and other obstacles that pertain to risk and vessel design are discussed in the following section.

\section{Alternatives to Traditional Container Barge Operation}

The traditional means of barge movement has been by being towed or pushed between ports. Alternative ways of moving barges is now being explored. This has been to reconsider the LASH (lighter aboard ship) and "float/on float/off” (FLO/FLO) technologies for carrying barges. LASH is also termed "lift/on lift/off” (LO/LO), and the rationale for the lash or LO/LO applies to the FLO/FLO methods of transport for barges and other equipment.

The lighter aboard ship LASH is designed to carry lighters (barges) where they are lifted by crane on to the vessel. The LASH comes in different configurations. Some can accommodate over 24 barges. Each barge may carry 600 to 1,000 metric tons of cargo, which is much bigger than the ocean freight container. It floats, is towed up and down a

32 Schwarz, J. "Inland Navigation Concerted Action: State Of The Art Report," Hamburg: INCATS, European Commission, VII, December 1997 (www.neptune-europe.org/hsva/State906.html) 


\section{Page 22}

river or canal, and is often referred to as a floating container. The LASH itself is useful in moving a relatively large volume of cargo in the short-sea trade and to and from sites on rivers and canals that cannot be used by the larger ocean vessels. The LASH keeps the load in the same vessel for the entire trip, thus reduces cargo handling, transport costs and time. The LASH is popular in Europe, taking advantage of the extensive inland waterway systems which are the cheapest means of inland transport in moving goods from landlocked regions to seaports and transfer to the ocean vessels. ${ }^{33}$ It is important to note that the LASH has not been successful in all applications due to equipment requirements (on board cranes) and regulation of shipping in many countries. Cabotage laws, for example, in various countries with inland water transport systems may preclude the use of LASH technology. This led to the demise of several large carriers that put them into service in the 1970s. Pacific Far East Lines (an American flag vessel) for example, pioneered the use of LASH vessels in the Far East, South Pacific and Persian Gulf trades but had trouble securing markets in the areas they were designed to serve due to cabotage laws and the company had to file for bankruptcy in the late 1970 s. $^{34}$

\section{FLO/FLO or LO/LO Barge Carriers}

The FLO/FLO technology is being looked at as a more efficient system than the LASH and LO/LO technologies. FLO/FLO is now being used by the military and the shipping industry for loading and moving barges and other equipment. One example of the traditional design that is being used is shown below. It is known as a partially submerged vessel in that it can submerge its loading deck to sufficient depth for loading barges and other equipment. The vessel Teal in Figure 11 (shown left), owned by Dockwise Shipping of the Netherlands,

\footnotetext{
33 http://www.export911.com/e911/ship/roro.htm

34 WEST COAST SAILORS, Volume LXV No. 2, February 22, 2002, and discussions with Professor Emeritus, Douglas K. Fleming, Transportation Geographer, University of Washington, June 2003.
} 
Page 23

delivered 24 barges and a push-boat to Argentina and 3 pontoons to Venezuela on a typical voyage in 1997. In order to stow 24 barges, 3 pontoons and a push-boat the cargo was transversely stowed on the Teal's cargo deck and stacked 3 high.

>>> Insert figure $11<<<<$

The load size was $126.8 \times 61 \times 16.7 \mathrm{~m}^{35}$ The right photo shows the Teal's sister ship the Swan as it has submerged for loading. The cargo deck of the 'Swan' measures $126.8 \times 31.6 \mathrm{~m}$. If containers were loaded on these vessels the same height and length as that load but $31.6 \mathrm{~m}$ wide (not extending over the sides), they would be stacked 12 wide, 6 high, and 20 lengthwise with a capacity of approximately 1440 TEUs.

In Europe, a FLO/FLO concept called the Combined Traffic Carrier Ship/Barge (CTCB) is being developed and is based on what they term the Trans Sea Lifter (TSL). ${ }^{36}$ This is a catamaran type vessel that is designed to carry barges used in inland water navigation. The vessel is designed to partially submerge and loads/unload barges in a similar fashion to that of Dockwises's vessels as shown above. The TSL would make regularly schedules stops at the entrance to inland waterways to pickup and drop off barges in a staging area. The barges would be moved to and from inland ports by tugboats while the TSL moves on to its next stop on its round trip voyage. The proposed vessel's dimensions are length $182.3 \mathrm{~m}$; draft $10 \mathrm{~m}$, and width 76.5 which is the length of the Europe IIa standard sized barge. This vessel would be able to carry 6 of the Europe IIa

\footnotetext{
35 http://www.dockwise.be/start-othermar.html

36 Peterlini, Edoardo, “Innovative Technologies for Intermodal Transfer Points,” European Union, Marine Technologies for Marine Transport, Competitive and Sustainable Growth Programme, June 2001.
} 
barges with 102 TEUs each for a total capacity of 621 TEUs. The estimated cycle time for submerging floating off all barges, floating on another load and re-floating is 90 minutes. ${ }^{37}$

Another type of FLO/FLO barge carrier that offers a unique solution to increasing volumes of marine cargo without the concern of deepwater channels, ports, and larger terminals that are needed to handle mega ships has a "trapezoidal” hull design that loads from the stern as opposed to the catamaran style hull design in the TSL FLO/FLO system that loads from the side. ${ }^{38}$ The trapezoidal hull increases the stability of a vessel designed for barge carrying. The innovative-patented trapezoidal hull form has been shown to reduce propulsive resistance, increase stability and deck space and cubic capacity of the cargo compared to a conventional ship with the same displacement. A U.S. Department of Energy study stated that the "unique trapezoidal .... suggest some advantages over the traditional ship designs in propulsive efficiency and sea keeping ability."39 Incorporated into the hull of this vessel is a floating dry dock similar to the Dockwise vessels and the TSL concept which is capable of accommodating the cargo in multiple separate float-on / float-off barges. This vessel however, loads and unloads from the stern similar to the Dockwise yacht carrier as shown in Figure 12. Dockwise has two of the stern-loading vessels with a maximum deck space of $32 \times 140 \mathrm{~m}$. This would be enough to accommodate a stack of containers one high by 15 wide by 23 long for a total of 345 on one level. If the containers were in barges stacked 3 high to clear most bridges, the vessel's capacity would be approximately 1000 TEUs.

$$
>>>>\text { Insert figure } 12<<<<
$$

\footnotetext{
37 Ibid

${ }^{38}$ Browning, Jess (Ed.), “The Jumbo Barge Carrier: An Ocean Transportation System for the Twenty-First Century," A monograph and working paper, (July 2003) that was compiled in part from discussions with Tornqvist who patented the system in March 1998.

39 U.S. Department of Energy titled “Innovative/Alternative Transport Modes for Movement of U.S. Coal Exports to the Asian Pacific Basin”, March of 1990.
} 
The rear loading, trapezoidal-hull barge carrier is designed as a "mother ship" for multiples of float-on / float-off barges. For the largest type mother ship, 6 barges can be designed to handle up to 2,000 TEUs each for a total of 12,000 TEUs. Either large or small, the barges are capable of accommodating containers as well as RO/RO cargoes and bulks. It is possible for the larger mother ship make a transoceanic voyage with a combination of all these different cargoes.

In either case, a FLO/FLO mother ship makes it possible for a port to handle increased capacity without investing in deep channels. The barge carrier can discharge and reload its barges in deep water outside the main port area. Essentially, the mother ship arrives in a sheltered area of a load center port and ballasts down allowing the barges to discharge and/or load by floating on and off the vessel. Tugs tow the barges to marine terminals in the hub port or to ports on inland waterways and are then stevedored as conventionally. The larger barges require only 6 to 9 meters of water, well within the capabilities of most of today's container ports and many inland waterways. The smaller barges can be built with a draft depth to operate in the waterways they are designed to serve. It is important to note that the barges can be dispersed among several terminal facilities to make better use of the port facilities and avoid road congestion as well as rail congestion. Unloading and loading of the barges can take place at a more leisure pace during regular working hours, thus avoiding high overtime expense.

\section{The FLO/FLO Vessel as a Floating Transshipment Terminal}

In the case of short sea shipping either for direct shipment or transshipment to out ports 400 to 1000 miles from coastal and inland waterway staging areas, a smaller mother ship would be used that could carry multiples of smaller barges. In the case of ocean service vessels, a 
larger mother ship would be used to take advantage of economies of scale. Both types of vessels, large and small can be designed with an on board crane mounted on side rails to shift containers from one barge to another while underway maximizing loading efficiencies. The loaded barges can be built with cells to prevent side to side movement of containers. They can be un-stacked from one barge and restacked on another for discharge at the next port of call. This would simplify the logistics of loading containers at an inland port on a barge that would be making several stops in direct trade or feeder trade. The mother ship in essence would become a floating terminal similar to that reported in a study on maritime technologies for intermodal transport. ${ }^{40}$ This stern-loading FLO/FLO designed vessel would be able to perform a transshipment function while underway in calm seas or in a sheltered area arriving at a river mouth, a coastal port, or a hub port with the right combination of containers on a barge that would be floated off and replaced with another in a matter of minutes or, at most, a few hours.

\section{Short Sea Shipping}

The Yellow Sea transportation system should be developed as an intermodal short sea shipping system combining various modes such as sea, air, road, rail and inland waterway to achieve competitiveness. It has been pointed out above that research on several engineering problems should be performed to successfully implement the Yellow Sea transportation system. A fast transportation requires rapid cargo transfer from one mode to another to minimize the interruption in cargo flow (see Figure 13). Port time has to be minimized by employing ships with excellent maneuverability, customized automatic docking systems and improved inter-modal terminals.

$$
\text { >>>> Insert figure } 13<<<<
$$

\footnotetext{
${ }^{40}$ Peterlini, Edoardo, “Innovative Technologies for Intermodal Transfer Points,” European Union, Marine Technologies for Marine Transport, Competitive and Sustainable Growth Programme, June 2001
} 
Ships are the most important element for the Yellow transportation system and the roles of the fast ships in the short sea shipping are increasing rapidly. The operating speed of a ship should be chosen to meet the needs of the specific route it serves. Short sea shipping in the Yellow Sea region may require fast ships to compete with land modes such as rail or road. Sea-air mode also need fast ships to transfer cargoes rapidly between regional and hub airport (see Figures 13\&14). The fast ships will mostly handle containers and $\mathrm{RO} / \mathrm{RO}$ trades as well as the passengers since there is no need for bulk cargoes to move fast by sea. Types and principal dimensions of the ships should be chosen to be suitable for the specific routes and the ship has to be designed to allow fast cargo handling. The excellent maneuvering capabilities and stabilities are required for the ships to minimize the port time. The ships may have a capability to economically collect cargoes from several ports in a voyage. Ships for connection of inland waterways to the Yellow Sea will further enhance competitiveness of the Yellow Sea transportation system. Development of seariver going container ships and barge systems for coastal as well as inland waterways can enhance trade among the countries in the region.

\section{>>> Insert figure $14<<<<$}

The ports on the coast of the Yellow sea suffer from large tidal differences. For example, the tidal differences in Incheon area exceeds 9.7 meter and this will considerably retard fast turn around of the ships. Terminals for short sea shipping have no need to be located in the existing ports. Considerable cost and time will be saved if the terminals are located at the vicinity of a distribution center and transshipment also can be carried out 


\section{Page 28}

outside a port by exploiting floating terminal technologies. Figure 15 shows artists perception of the floating terminals.

>>>>Insert figure $15<<<<$

The time required for loading and unloading cargo takes a significant portion of the total operating time in short sea shipping and terminals for the fast ships and the design of fast cargo handling systems to minimize port time should be undertaken and implemented. For example, Incheon and Dalian are only 288 nautical miles apart and it takes about 10 hours for a 30 knots class high speed container ship to make the trip. Daily round trips on the route will be possible if port time for loading and unloading of containers can be confined within 2 hours at the each port. A terminal with dedicated facilities for quick and smart cargo handling and for mooring of the ship will be necessary. Standardization of port facilities and equipments as well as cargo handling units will be necessary. Figure 13 shows schematic diagrams of the fast cargo handling systems for reduction of loading/unloading times and to overcome tidal differences (see right picture in Figures 13-15).

Support for the Yellow Sea transportation system will depend on collaboration between Korea and China. The organization of a bilateral committee or Korea-China forum for Yellow Sea Transportation in order to promote cooperation of the two countries in utilizing a Yellow Sea transportation system could go along way to enhancing the mutual understanding and the highly beneficial development of short sea shipping to both countries. Members of any such forum should consist of high rank bureaucrats, scholars, researchers and businessmen from various fields. Support from commercial and industrial sectors and collaboration with researchers will be also essential for the success of the system since 
Page 29

commercialization is one of the most important factors in its development. ${ }^{41}$.

\section{SUMMARY AND CONCLUSION}

This paper has explored what the Incheon Region has been, and is doing to create, expand, and improve value-added logistics facilities as well as integrate their intermodal transportation systems in order to enhance their position as a regional hub. It has looked at how Northeast Asia trade flows might be enhanced in the Incheon region by application of the Pentaport model with respect to logistics related services and transportation systems in China and Korea as well as the need for more education and training of professionals in the logistics field. It has looked at water transportation in China, its potential for growth and the need to overcome its obstacles. It has proposed an integrated transportation system for the Yellow Sea region being beneficial to the economies of the Northeast Asia. It has been stressed that innovative technologies for ships, terminals and cargo handling systems should be introduced to realize competitive short sea shipping system in the region. Cooperation among the regional countries will be essential to achieve the final goal. Finally, it has explored the potential of new methods of container shipping and how it could serve inland water transport and short sea shipping in the Yellow Sea Region as related to the pentaport model.

The maritime industry is facing a crisis - the shipping container has enabled the world to trade commodities on a scale that was unimaginable just a few decades ago. In order to accommodate the increase in container volumes moving in and out of marine ports there has to be alternative to existing methods. Fast RO/RO ships and the FLO/FLO barge carrier system should be considered for short sea shipping and inland water transport as well as ocean shipping in addressing logistics problems and the needs of ports, shippers,

\footnotetext{
${ }^{41}$ Lee, Jae Wook and Lee, Seung-Hee, “On the Transportation System of the Yellow Sea in the $21^{\text {st }}$ Century”, ICET 2000, Chinese Academy of Engineering, Beijing, China, October 2000
} 


\section{Page 30}

carriers, and the consumer. Serious consideration should be given to government-sponsored research, in the context of the Pentaport model, leading to the development and application of enhanced vessels such as the FLO/FLO (including the floating terminal type) for transport of inland waterway container barges on short sea shipping routes in Northeast Asia. Full utilization of inland waterways in Korea is inevitable and infrastructures for the purpose need to be constructed. In this sense, resumption of the discontinued Kyung-In canal project will be necessary to connect Han River and the Yellow Sea. This effort would greatly enhance Korea's situation with respect to container shipping on the Yellow Sea and becoming the logistics and business hub of the broader region.

Research on the above engineering topics, as well as political and economical assessments on the Yellow Sea transportation system will be necessary. The cooperation among countries in the region is the most urgent and important for establishment of the Yellow Sea transportation system. An organization of a bilateral consortium for promotion of the Yellow Sea Transportation system is recommended such as the "Korea-China or China-Korea Yellow Sea Forum.” Such a forum would enhance and promote intergovernmental cooperation on policy-making and regulation as well as the cooperation among the research institutions and industries of the both countries. 


\section{REFERENCES}

Browning, Jess, "Development of Logistics and Transportation Systems in Promoting Trade \& Economic Growth: Comparing Incheon and Seattle Areas,” Korean Observer, Vol. 34, No. 3, Autumn 2003.

Browning, Jess (Ed.), “The Jumbo Barge Carrier: An Ocean Transportation System for the Twenty-First Century,” A monograph and working paper, (July 2003) compiled in part from discussions with Bengt Tornqvist who patented the system in March 1998.

Chang, Young-Tae,” Korea’s Strategic Plan to be Northeast Asia’s Logistics Hub: Chang, Young Tae, “Towards the Pentaport Approach,” A Working Paper, Inha University Workshop, October 2003.

China (The World Fact Book) January 1, 2003

Chin-Soo Lim, "Study on Container Throughput Forecasting for Shipping and Port Development Strategies in the APEC region,” A Project Proposal by the Shipping, Logistics and Port Research Center, Korea Maritime Institute (KMI), Presented to the Port Experts Group at the 22nd meeting of the APEC Transportation Working Group in Busan, Korea (September, 2003).

Cho, Lee-Jay and Kim, Yoon Hyung, (eds.), “Building an Integrated Transport Market for China, Japan, and Korea: Elimination of Barriers,” The Korea Transport Institute and the East-West Center, 2002

Donald Urquhart Shipping News, Business Times, June 24, 2003.

DOTARS, “Freight Logistics in Australia: an agenda for action,” June 2002, p5

Jim Dai, Shi-Jie Deng, Jihong Ou, Kwok-Leung Tsui, Yang Wang, Huiwen Zhang, Wang Derong, Liu Xiaohong and Li Rui “China Logistics Provider Survey,” The Logistics Institute, National University of Singapore, January 2003.

The World Fact Book, Korea, January 1, 2003

Korea Times 2002/02/03

Lee, Jae Wook.and Lee, Seung-Hee. et al, "On the fast sea transportation system for Incheon \& Yongjong Islands (Incheon International airport)”, Report, Incheon Metropolitan City, 1999

Lee, Jae Wook and Lee, Seung-Hee, “On the Transportation System of the Yellow Sea in the $21^{\text {st }}$ Century”, ICET 2000, Chinese Academy of Engineering, Beijing, China, October 2000

Browning, Jess (Ed.), “The Jumbo Barge

OECD Organization for Economic Co-operation and Development, Abstract: Source Industry, Services \& Trade, August 2002. 
Page 32

Peterlini, Edoardo, “Innovative Technologies for Intermodal Transfer Points,” European Union, Marine Technologies for Marine Transport, Competitive and Sustainable Growth Programme, June 2001

Schwarz, J. "Inland Navigation Concerted Action: State Of The Art Report,"

Hamburg: INCATS, European Commission, VII, December 1997.

Schinas, O.D., Paraftis, H.N.,"New frontiers through short sea shipping”, SNAME Transactions, Vol.105, 1997

Spear, Andrea; Nailer, Chris; and He Susan, China Infrastructure: Sectoral Plans, Reforms and Financing, East Asia Analytical Unit, Department of Foreign Affairs and Trade, Australia, Briefing Paper Series No.6, JULY 1997.

U.S. Department of Energy titled "Innovative/Alternative Transport Modes for Movement of U.S. Coal Exports to the Asian Pacific Basin”, March of 1990.

UN/ESCAP, “Regional Shipping and Port Development Strategies Under a Changing Maritime Environment,” Maritime Policy Planning Model, 2001.

Wang,Yang, “China Logistics: Past, Present and Future,” Atlanta: Georgia Institute of Technology, 2002.

West Coast Sailors, Volume LXV No. 2, February 22, 2002.

Wu Ming, "Blueprint for Transportation Sector: China Opens Transportation Sector (2001/08/15)” http://www.chinese-embassy.org.uk/eng/16913.html. 
Page 33

Figure 1: Pentaport Assets of Incheon Metropolitan City

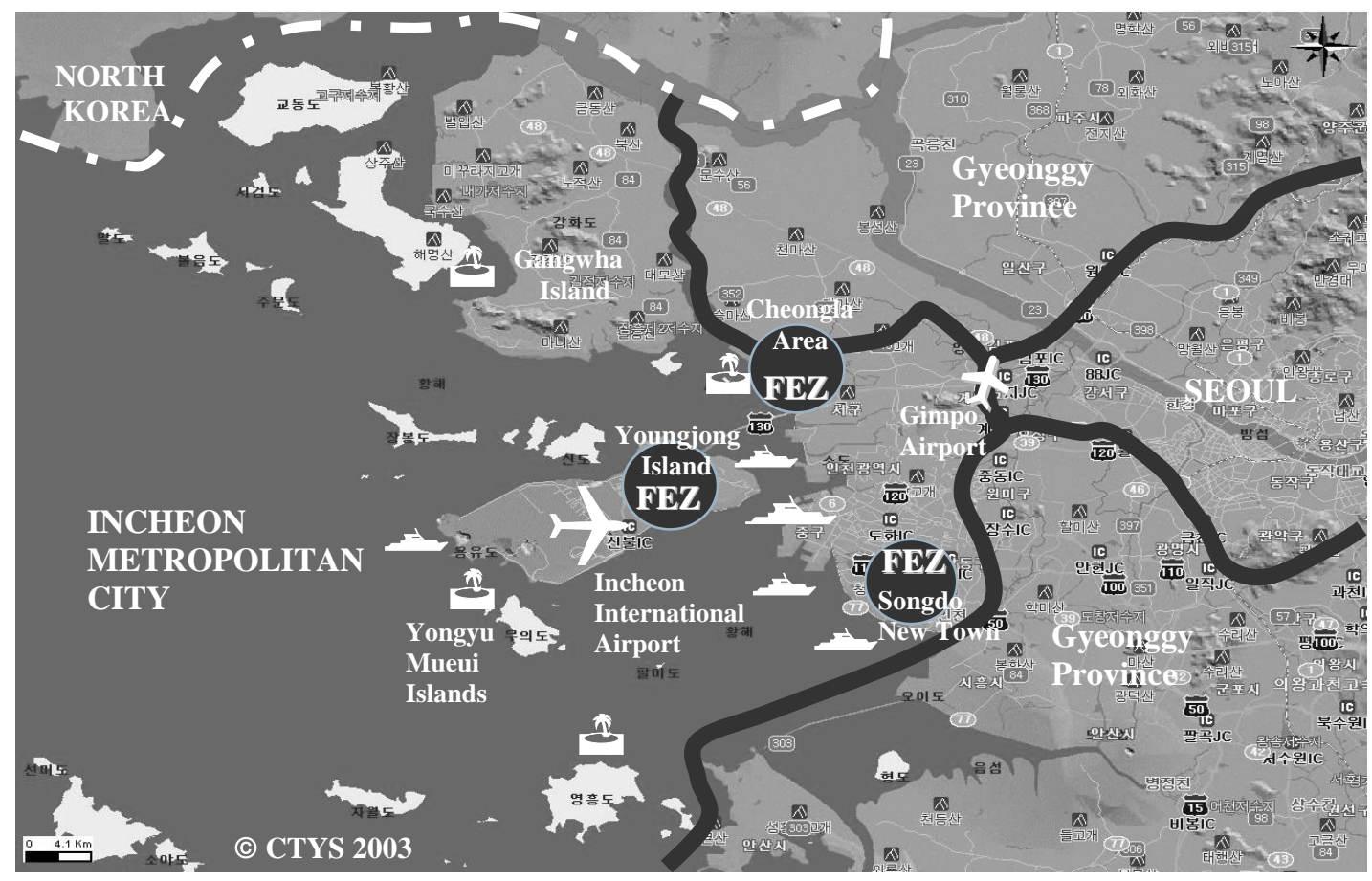

Source: Lee, Seung-Hee, "Future Aspects of the Yellow Sea Transportation and Logistics", Pentaport

Seminar to Develop Incheon as Logistics Hub in Northeast Asia, Inha University, October 27 28, 2003. 
Page 34

Figure 2: Inland Ports, Rivers \& Coastal Ports in the Yangtze - Yellow Sea Region

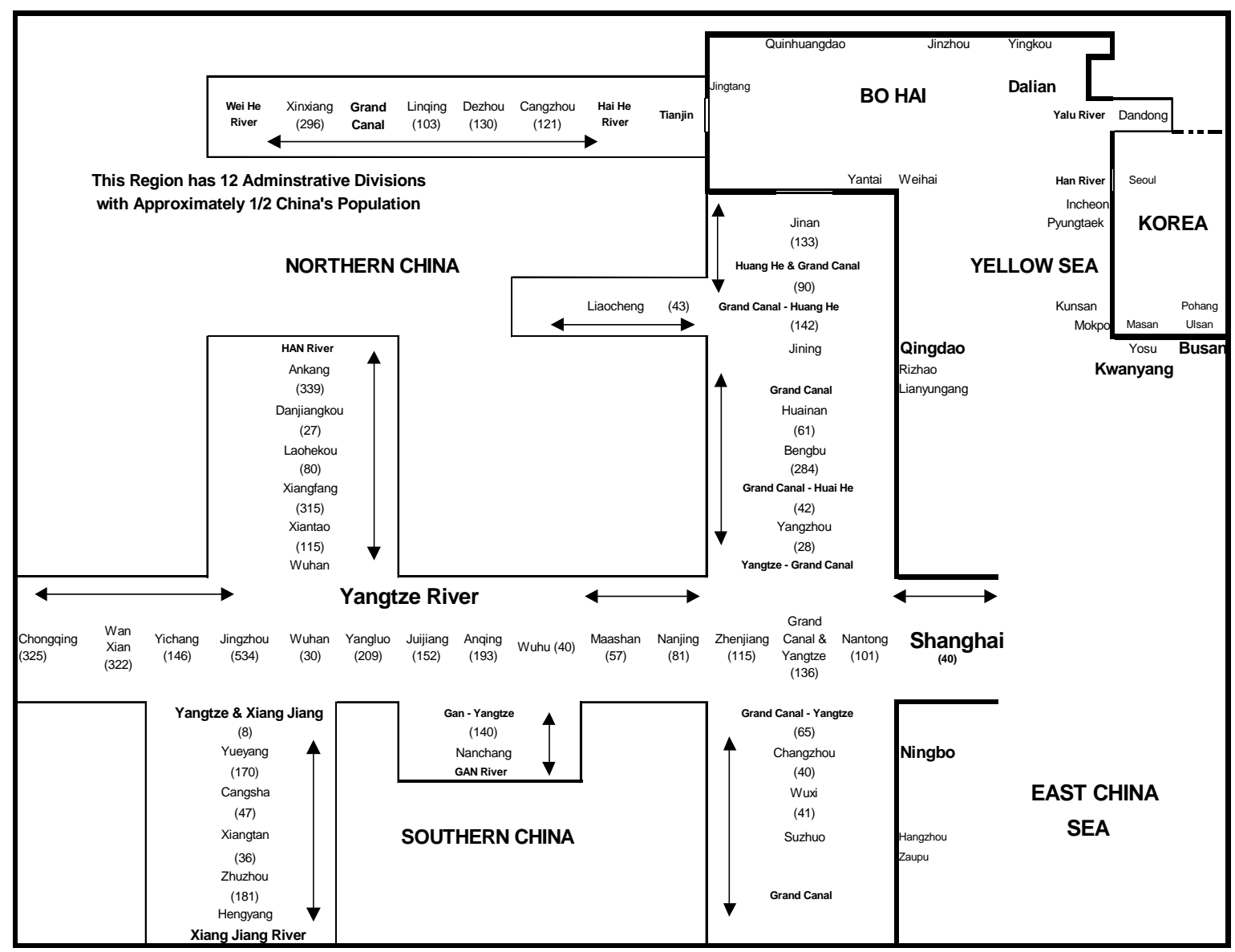

Source: Jess Browning, Journal of International Logistics and Trade, Volume 1, Number 1, December 2003 
Page 35

Figure 3: Shipping Services between China \& East Asia

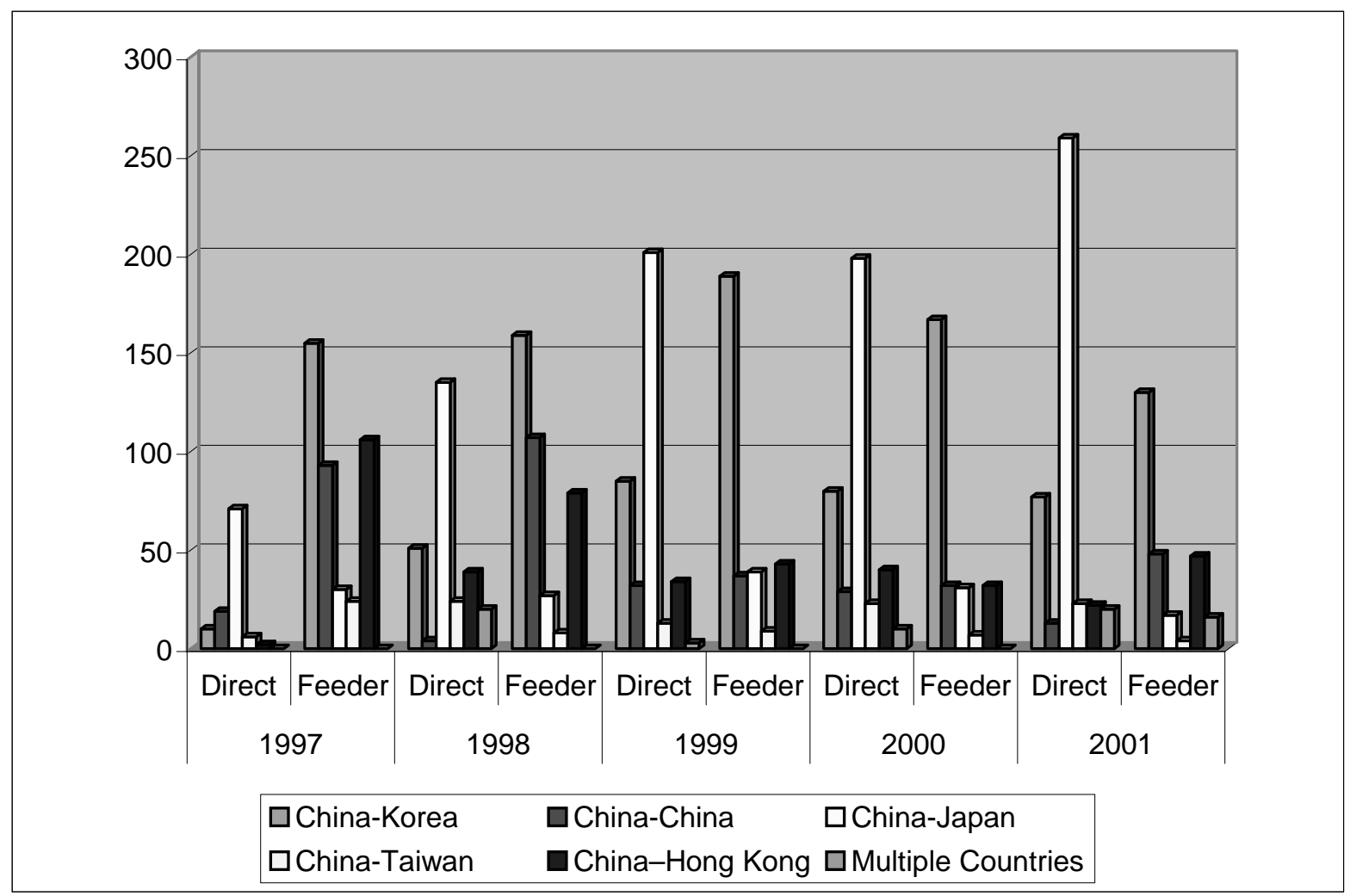

Source: China Shipping Gazette (2002) 
Page 36

Figure 4: Direct Shipment versus Transshipment in China Trade

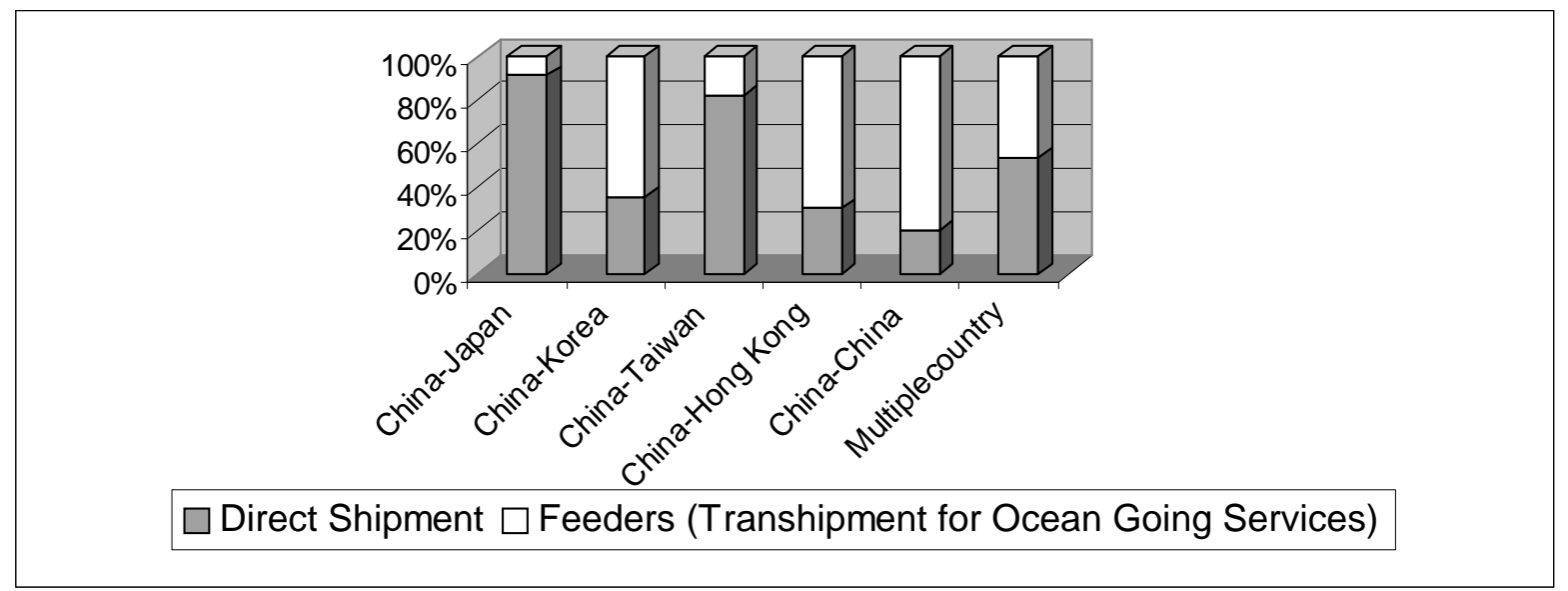

Source: NEA container shipping, 2001 


\section{Page 37}

Figure 5: Major Destinations of Four Chinese Ports

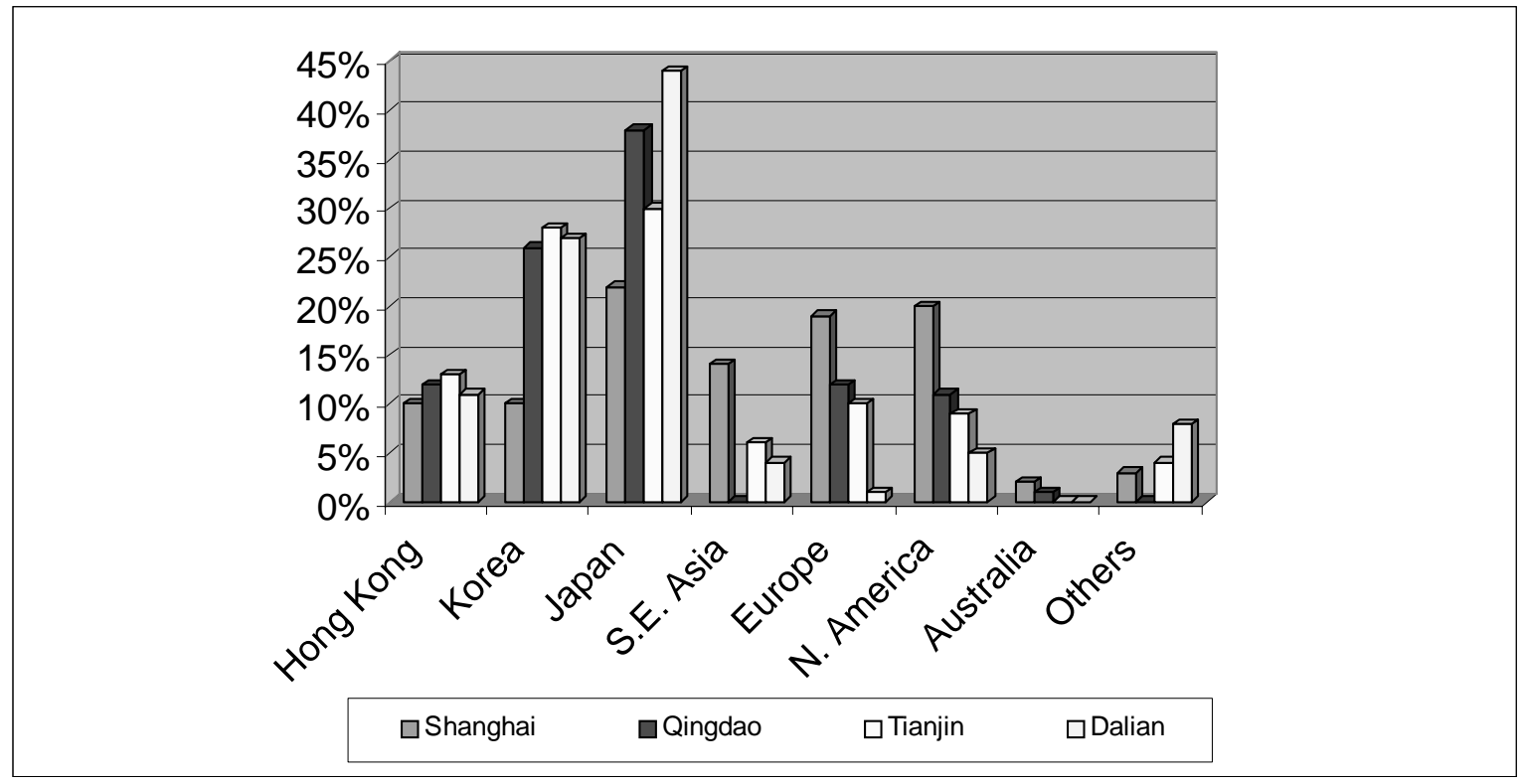

Source: Korea Transportation Institute \& East West Center (2002) 
Page 38

Figure 6: World Container Volumes

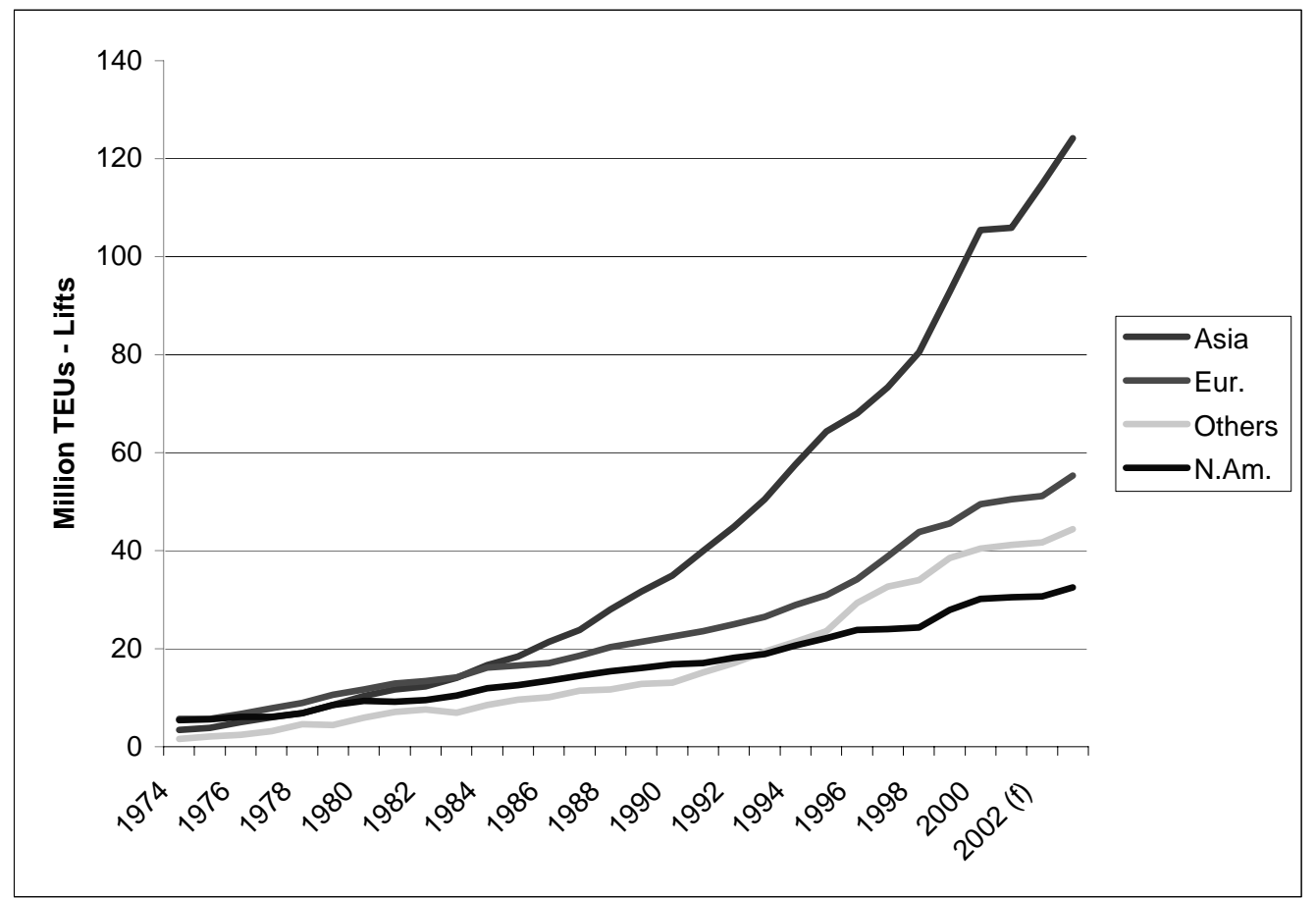

Data Source: Clarkson Research Studies (CONTAINER INTELLIGENCE QUARTERLY, $4^{\text {th }}$ Quarter 2002) 
Figure 7: The central location of Incheon and major railways in the Northeast Asia

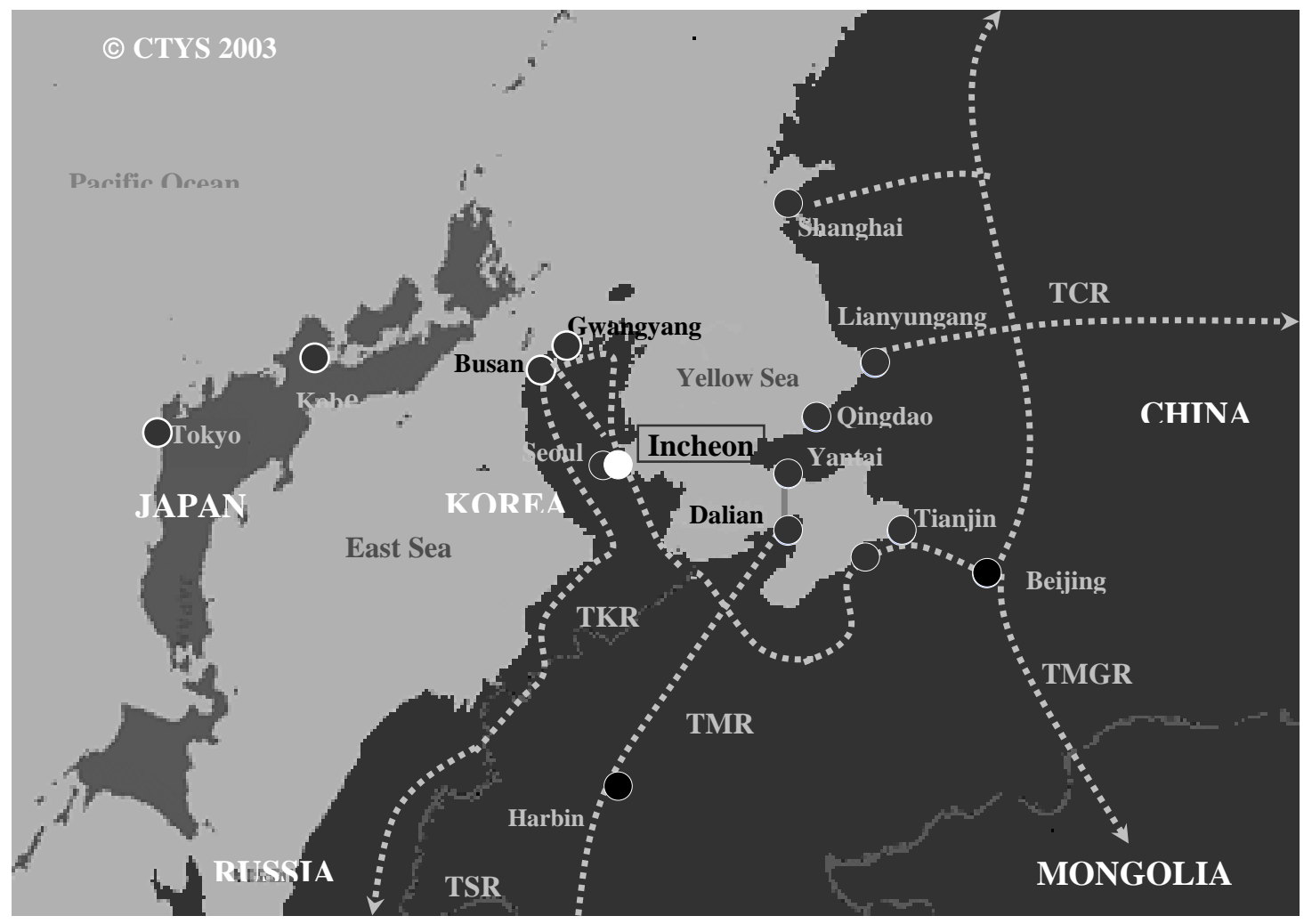

Source: Lee, Seung-Hee, "Future Aspects of the Yellow Sea Transportation and Logistics", Pentaport Seminar to Develop Incheon as Logistics Hub in Northeast Asia, Inha University, October 27 28, 2003 
Page 40

Figure 8: The Yellow Sea Region and Incheon

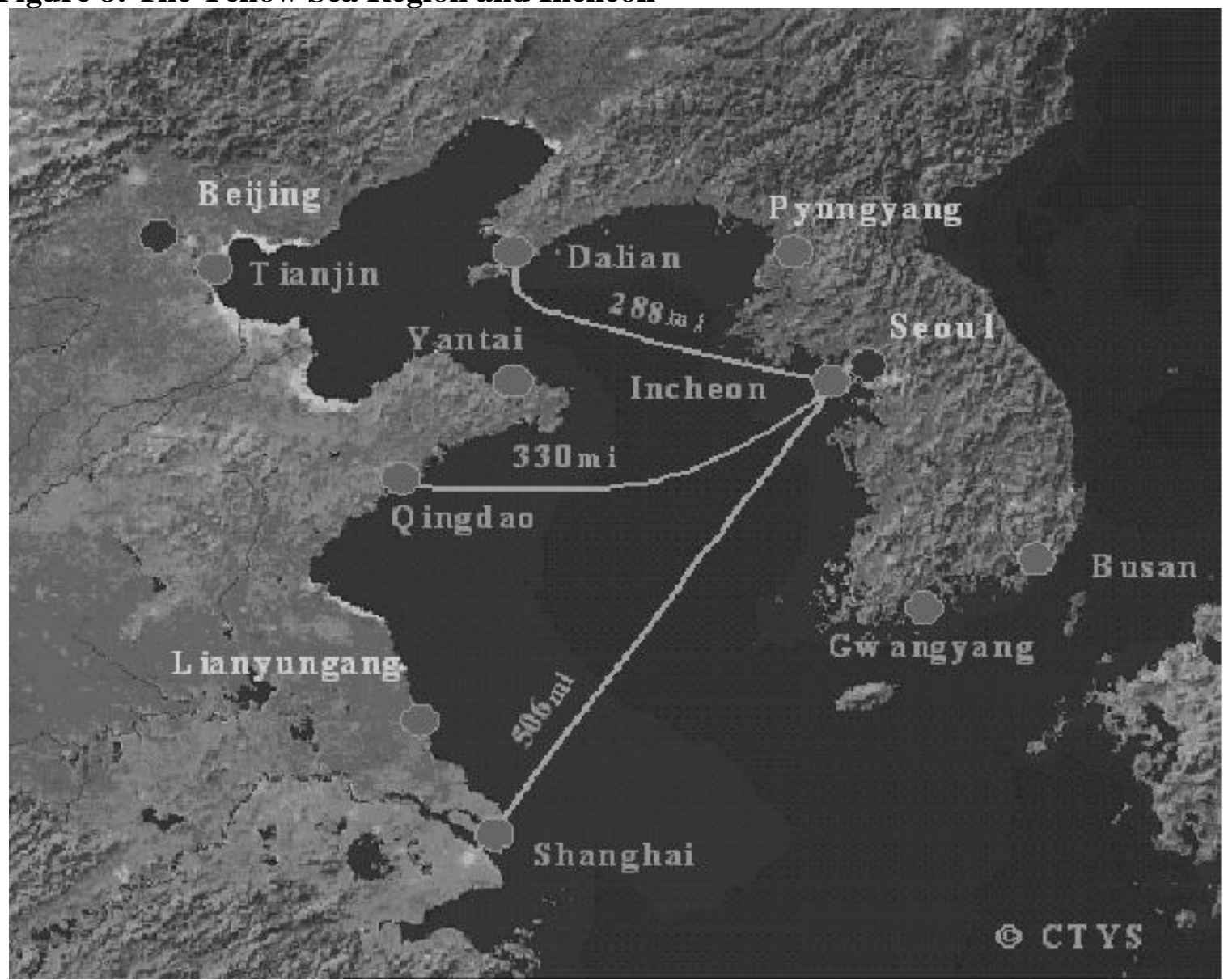

Source: CTYS 
Page 41

Figure 9: A Concept of the Yellow Sea Transportation System in Northeast Asia

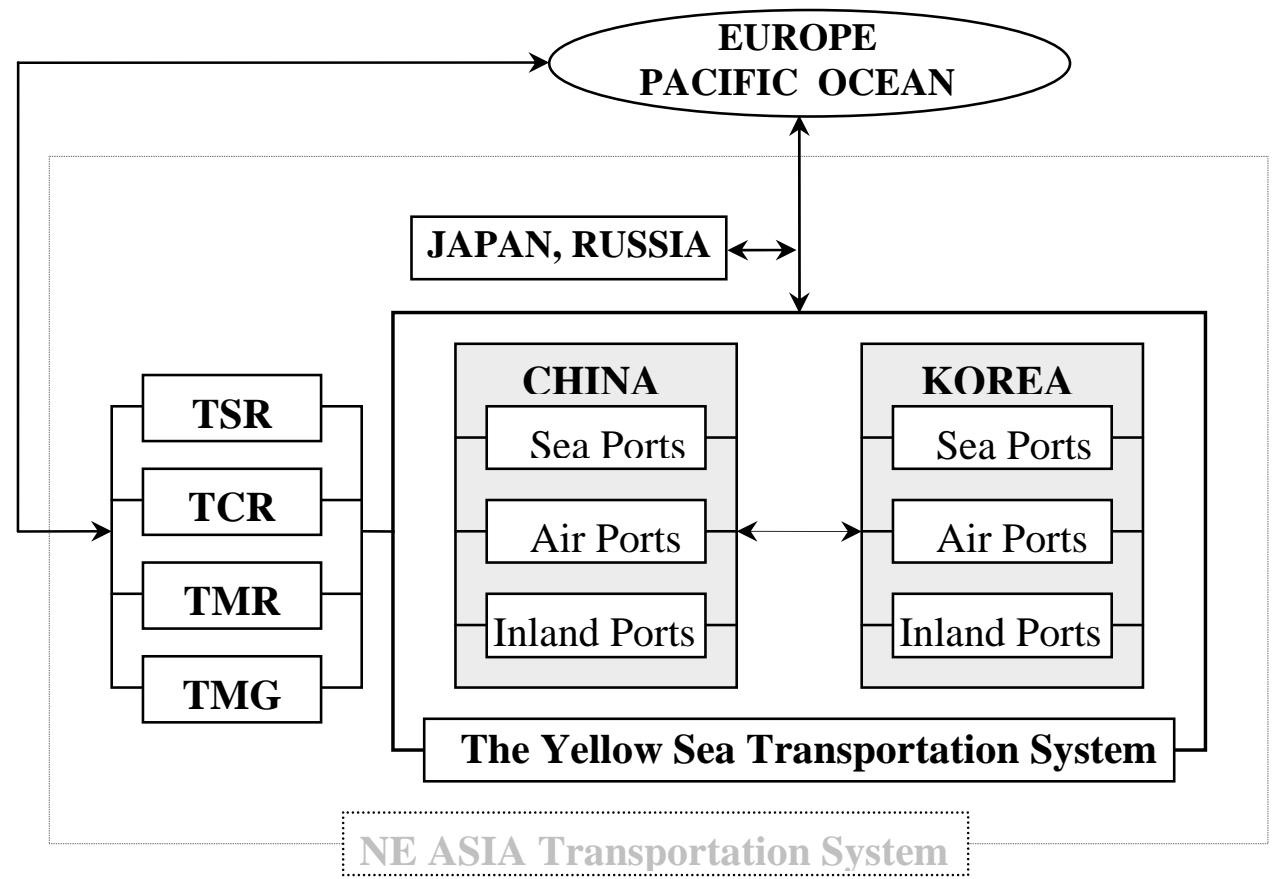

Source: Lee, Jae Wook and Lee, Seung-Hee, "On the Transportation System of the Yellow Sea in the $21^{\text {st }}$ Century”, ICET 2000, Chinese Academy of Engineering, Beijing, China, October 2000 
Page 42

Figure 10: A Container Barge towed along East Coast of US

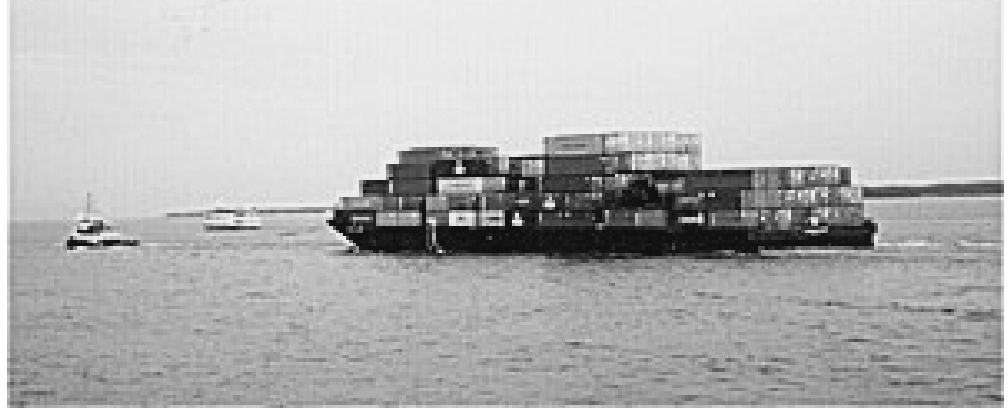

Source: Columbia Coastal (2003) 
Page 43

Figure 11: The FLO/FLO Type Barge Carriers

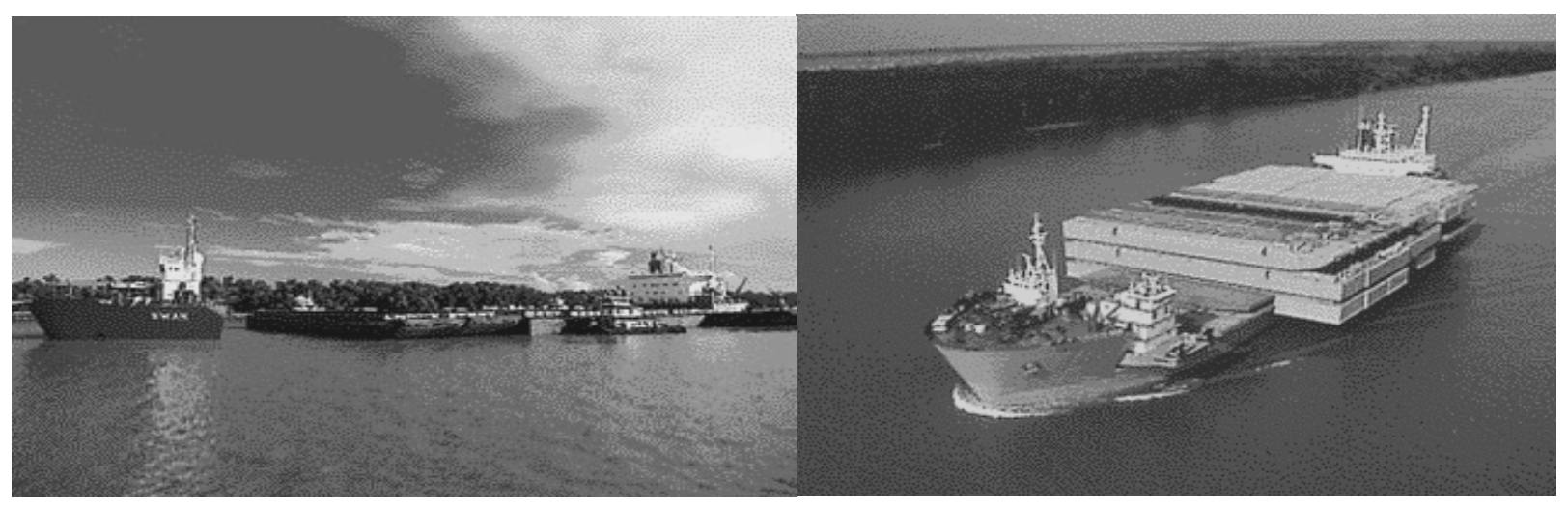

Source: Dockwise (2003) 
Page 44

Figure 12: A FLO/FLO Type Yacht Carrier

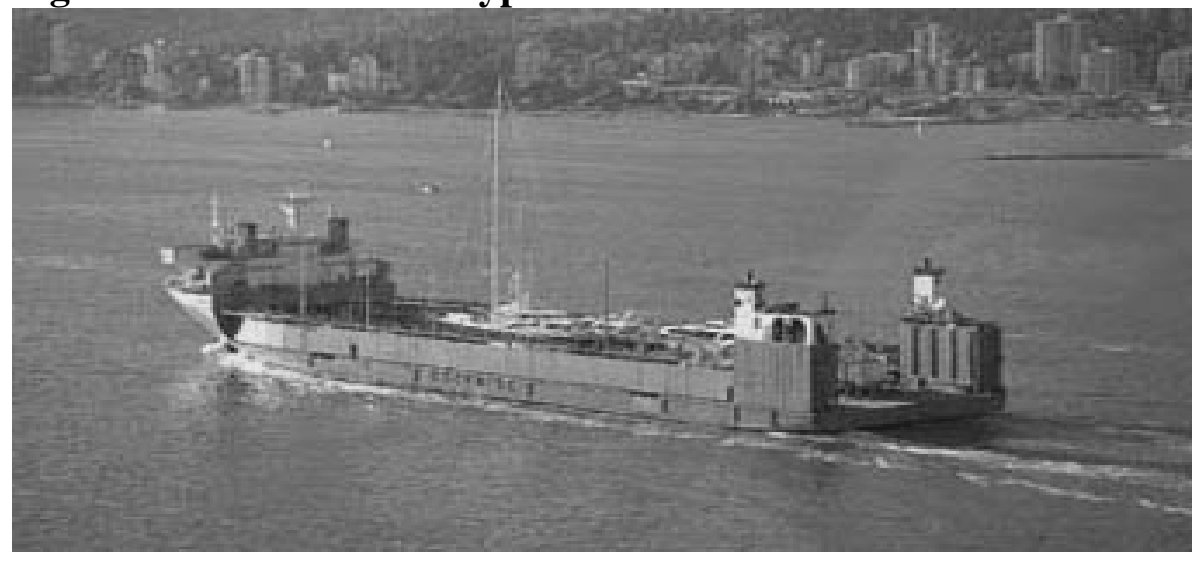

Source: Dockwise (2003) 
Figure 13: Fast Cargo Handling System

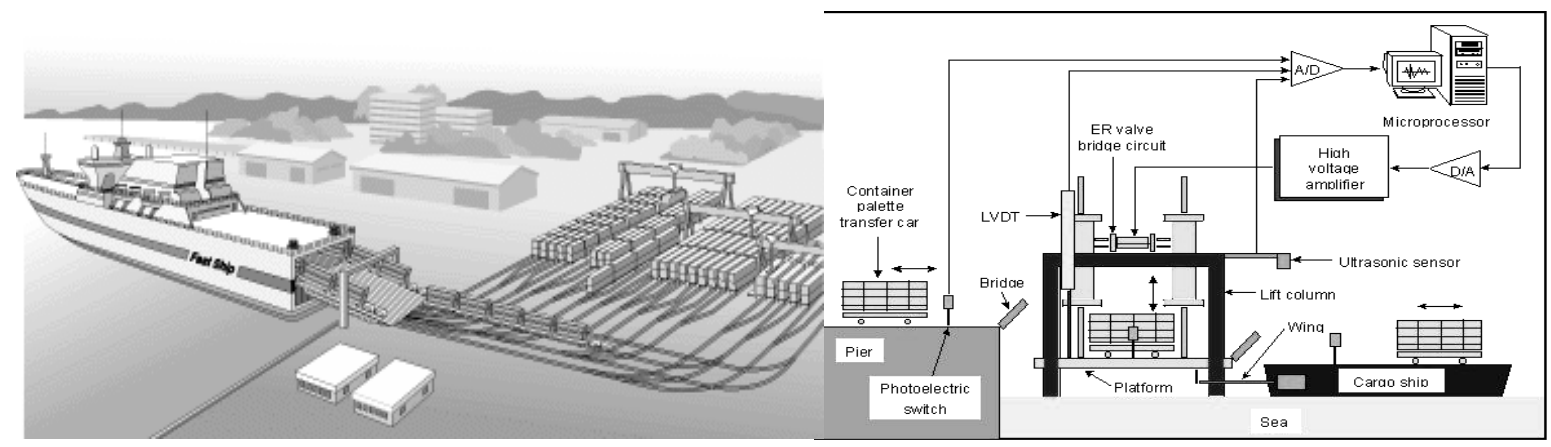

Source: Fast Ship (left), CTYS (right) 
Figure 14: Ships for Short Sea Shipping; New and Old Technologies; Slow and Fast

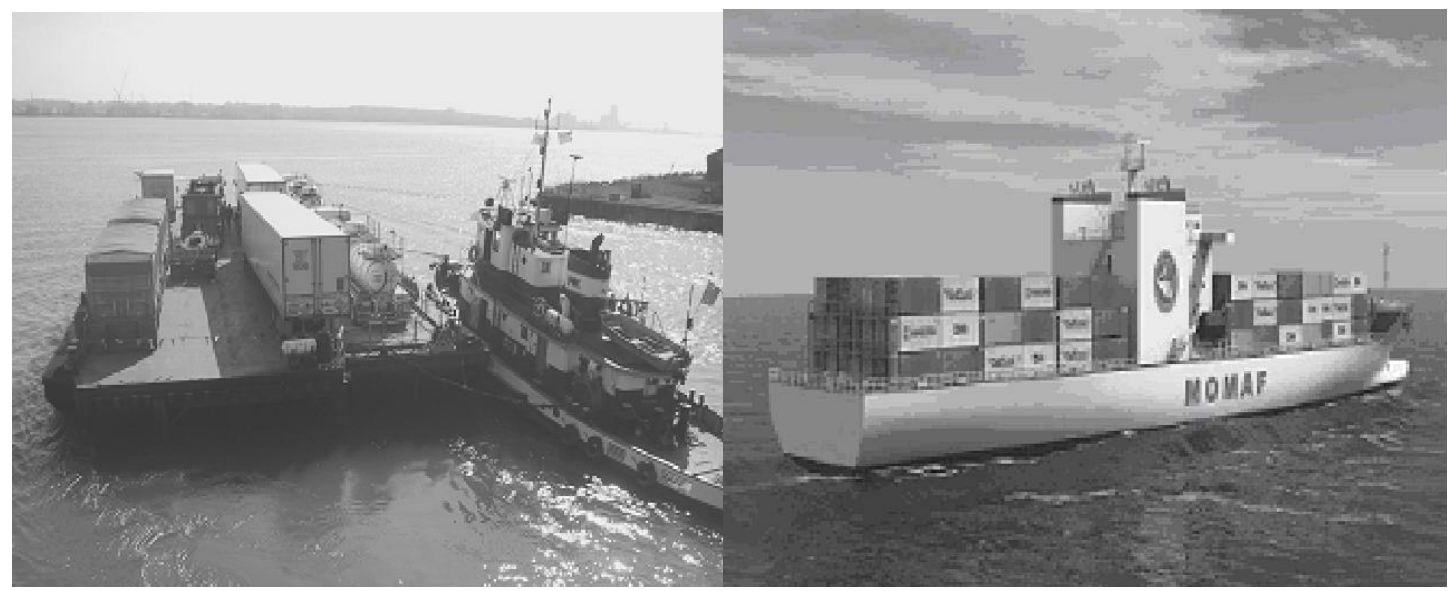

Source: J. T. Lee, Pentaport project 2003, Inha University 
Figure 15: Floating Terminals

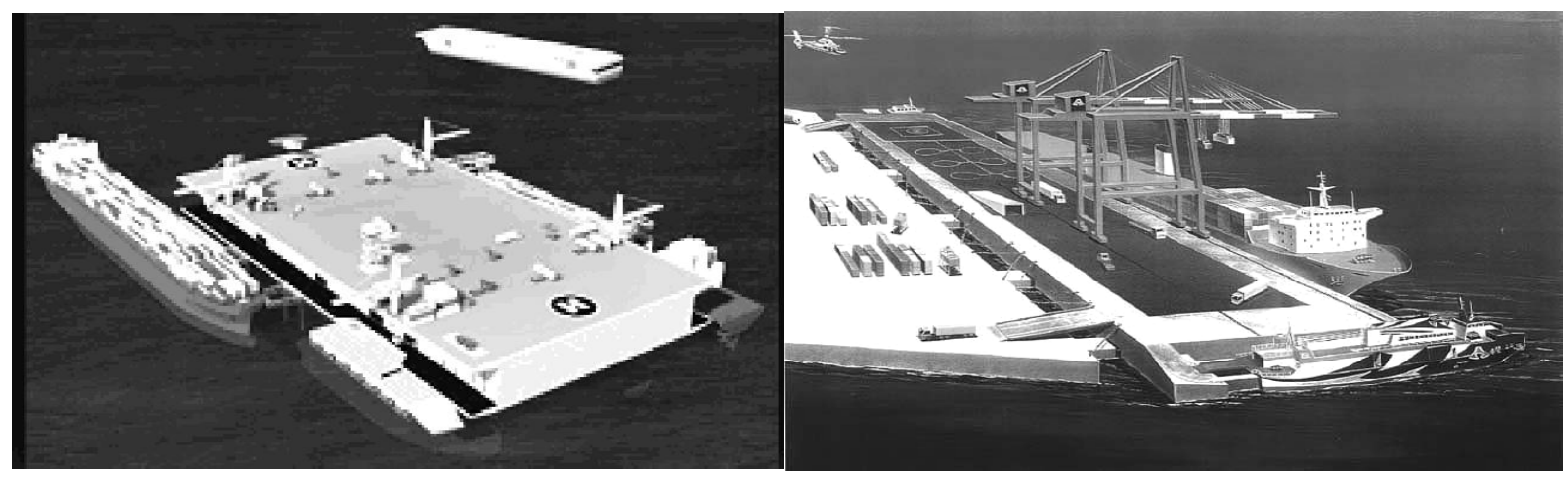

Source: J. T. Lee, Pentaport project 2003, Inha University 